UDK 272-789.2(497.581.1Zadar)“15”(091)

$272-9(497.5)$ "15"

Izvorni znanstveni rad

Primljeno: 26. kolovoza 2020.

Prihvaćeno za objavljivanje: 4. prosinca 2020.

\title{
POSJEDI SAMOSTANA BENEDIKTINKI SV. KATARINE U ZADRU (16. stoljeće)
}

\author{
Zdenko DUNDOVIĆ \\ Teološko-katehetski odjel Sveučilišta u Zadru \\ Ulica dr. Franje Tuđmana 24i, 23000 Zadar \\ zdundovic@unizd.hr
}

U radu se razmatra dosad neobjavljen inventar posjeda ženskoga benediktinskog samostana sv. Katarine u Zadru iz 1599. godine, koji je pohranjen u Arhivu samostana benediktinki sv. Marije u Zadru. U inventaru su jasno naznačeni prostorni položaj, veličina, prihodi i koloni na posjedima ženskoga benediktinskog samostana sv. Katarine u Zadru u 16. stoljeću, a njihovom analizom nastojat će se prikazati gospodarski aspekti te redovničke zajednice, koja je u svoje redove primala isključivo pripadnice zadarskoga građanskog staleža. Podatci s kraja 16. stoljeća usporedit će se s izvješćem samostanskih prokuratora o samostanskim posjedima za razdoblje 1562. - 1564. godine iz arhivskoga fonda Državnoga arhiva u Veneciji (Archivio di Stato di Venezia) te dosad objavljenim rezultatima istraživanja.

KLJUČNE RIJEČI: samostan sv. Katarine, Zadar, benediktinke, posjedi, 16. stoljeće.

\section{Uvod}

Povijesne crtice o ženskom benediktinskom samostanu sv. Katarine u Zadru objavio je Carlo Federico Bianchi 1877. godine. ${ }^{1}$ On je naveo da nije moguće sa sigurnošću utvrditi početke samostana i crkve, ali se pretpostavlja da oni sežu prije 12. stoljeća. ${ }^{2} \mathrm{Na}$ Bianchijevu tragu isto je ustvrdio Ivan Ostojić u trilogiji o prošlosti benediktinaca u Hrvatskoj. ${ }^{3}$ Ostojić je preuzeo od Bianchija vijest o požaru 1110. godine, u kojemu su stradali samostan i crkva sv. Katarine, ali su ubrzo potom obnovljeni. Koludrice obnovljenoga samostana živjele su po benediktinskoj reguli, što je Bianchi ustvrdio na temelju dviju okolnosti. Prva je ta što je 1214. godine Katarina Butovan ${ }^{4}$ ostavila svoje zemlje u Bibinjama radi

\footnotetext{
Carlo Federico BIANCHI, Zara Cristiana, vol. I, Zara, 1877., str. 442-444.

C. F. BIANCHI, Zara Cristiana I, str. 442.

Ivan OSTOJIĆ, Benediktinci u Hrvatskoj, sv. II, Split, 1964., str. 90.

4 Zadarski plemićki rod Butovana dao je mnogo svećenika, dva biskupa, zadarskoga nadbiskupa, Ivana Butovana (1322. - 1332.) i hvarskoga biskupa Vida Butovana († 1322) te opaticu benediktinskoga samostana
} 
izgradnje oltara u čast sv. Benediktu u crkvi sv. Katarine u Zadru, a druga je ta da je 1240 . godine $\mathrm{u}$ istoj crkvi svečano misio rogovski opat Ivan. ${ }^{5} \mathrm{U}$ historiografiji su zabilježena $\mathrm{i}$ drukčija mišljenja o početcima primjene pravila sv. Benedikta u samostanu sv. Katarine u Zadru. Jedno od tih mišljenja je da se pravilo sv. Benedikta počelo opsluživati u tom samostanu koncem 14. stoljeća, nakon što su 1392. godine, na poticaj zadarskoga nadbiskupa Petra Matafara (1376. - 1398.) bile obnovljene trošne zgrade sv. Katarine obilatim darom Pelegrine Saladin, udove Franje Grisogona. ${ }^{6}$ Nedvojbena potvrda da su redovnice obnovljenoga samostana sv. Katarine obdržavale pravilo sv. Benedikta zapisana je u ispravi iz 1436. godine koja je pohranjena $u$ fondu Zadarskoga kaptola o obvezi podavanje desetine zadarskih samostana, koje je tada zastupao opat samostana sv. Krševana u Zadru Petar Kršava. ${ }^{7}$ Ivan Ostojić naveo je predaju prema kojoj je na otoku Ugljanu postojao hospicij benediktinki oblata na morskoj obali pod tvrđavom sv. Mihovila, koje su tu pod duhovnim vodstvom opata sv. Mihovila živjele do 1316. godine, kada su prešle u samostan sv. Katarine u Zadru. ${ }^{8}$ Nejasno je, međutim, o kojoj je crkvi i samostanu riječ. Čini se da se Bianchijevi i Ostojićevi osvrti na crkvu i samostan sv. Katarine u srednjem vijeku mogu odnositi jedino na crkvu koju je spomenuo Ivo Petricioli. Petricioli je upozorio na srednjovjekovnu crkvu sv. Katarine sa samostanom u zadarskom predjelu Babe (ad Babas), ${ }^{9}$ koja je zbog izgradnje citadele i pojačanja gradskoga zida nestala, a novi samostan, prema Petricioliju, preseljen je u centar grada početkom 15 . stoljeća. ${ }^{10}$ Petricioli je taj zaključak izveo na temelju Bianchijeva i Fiskovićeva podatka da se crkva spominje početkom 15. stoljeća, ${ }^{11}$ ali je ona izrijekom spomenuta u kupoprodajnom ugovoru od 3. travnja 1392. godine, sklopljenom između Pelegrine Saladin i Drage, udove Dragoja de Granbocianne, te je neupitno nova crkva sv. Katarine u centru grada izgrađena koncem 14. stoljeća. ${ }^{12}$ Po

sv. Marije u Zadru Katarinu Butovan, kći zadarskoga plemića Martinuša Butovana, koja je izgledno na toj službi bila barem od 1384. do 1403. godine. Usp. Serđo DOKOZA - Mladen ANDREIS, Zadarsko plemstvo u srednjemu vijeku, Zadar, 2020., str. 132-135.

5 I. OSTOJIĆ, Benediktinci u Hrvatskoj II, str. 90; C. F. BIANCHI, Zara Cristiana I, str. 442-443.

6 I. OSTOJIĆ, Benediktinci u Hrvatskoj II, str. 90. Usp. Emil HILJE, »Osvrt na najraniju povijest crkve i samostana sv. Duje na Pašmanu«, Radovi Filozofskoga fakulteta u Zadru. Razdio povijesnih znanosti, sv. 28, br. 15, Zadar, 1989., str. 137; Nada KLAIĆ - Ivo PETRICIOLI, Zadar u srednjem vijeku, Zadar, 1976., str. 241.

7 ....Sancte Catherine monialium ordinis Sancti Benedicti. Hrvatska - Arhiv Zadarske nadbiskupije - Prvostolni kaptol u Zadru 1401./1943. (dalje: HR-AZDN-18), kut. 17, br. 92. Usp. HR-AZDN-18, Liber privilegiorum, fol. 370-374.

8 I. OSTOJIĆ, Benediktinci u Hrvatskoj II, str. 69-70.

9 O tome da se samostan sv. Katarine nalazio u zadarskom predjelu Babe svjedoči zadarski katastik iz 15. stoljeća, iz kojega je razvidno da su benediktinke sv. Katarine posjedovale na tom mjestu neko drveno zdanje i nakon preseljenja u središte grada. Item unus locus terre, positus Jadre in confinio Bebarum, infra hos confines: undique sunt loci communis, super quo habet edificium de lignamine monasterium sancte Catharine. Stjepan ANTOLJAK, »Zadarski katastik 15. stoljeća«, Starine, sv. 42, Zagreb, 1949., str. 380.

${ }^{10}$ Ivo PETRICIOLI, »Lik Zadra u srednjem vijeku«, Grad Zadar. Presjek kroz povijest, Grga NOVAK - Vjekoslav MAŠTROVIĆ (ur.), Zadar, 1966., str. 167, 178.

${ }^{11}$ Isto, str. 154, bilj. 65.

12 Draga, relicta quondam Dragoy de Granbocianne, per se suosque heredes et successores iure proprio in perpetuum dedit, uendidit et tradidit domine Pellegrine de Saladinis, relicte Francisci de Grisogonis, fundatrici ac patrone sancte Catarine monialium de Iadra ementi et recipienti pro dicto monasterio sancte Catarine et eius monasterii conuentu vnum locum iuxta ecclesiam monasterii sancte Catarine nouiter fundati passuum quinque uel circa, cuius hii sunt confines: de borea possidet Ostoya condam Petri zapatoris, de trauersa uia publica, de austro et quirina loca sunt dicti monasterii, ad habendum, tenendum et possidendum et quicquid sibi nomine dicti monasterii et suis successoribus deinceps placuerit perpetuo faciendum cum omnibus et 
crkvi se taj gradski predio počeo nazivati predio sv. Katarine nove, ${ }^{13}$ a polovicom 15. stoljeća u spisima se navodi kao predio sv. Katarine u blizini Gospodskoga trga (Slika 1). ${ }^{14}$ Dakle, riječ je o crkvi i samostanu podignutima zaslugom Pelegrine iz zadarske plemićke obitelji Saladin. ${ }^{15}$

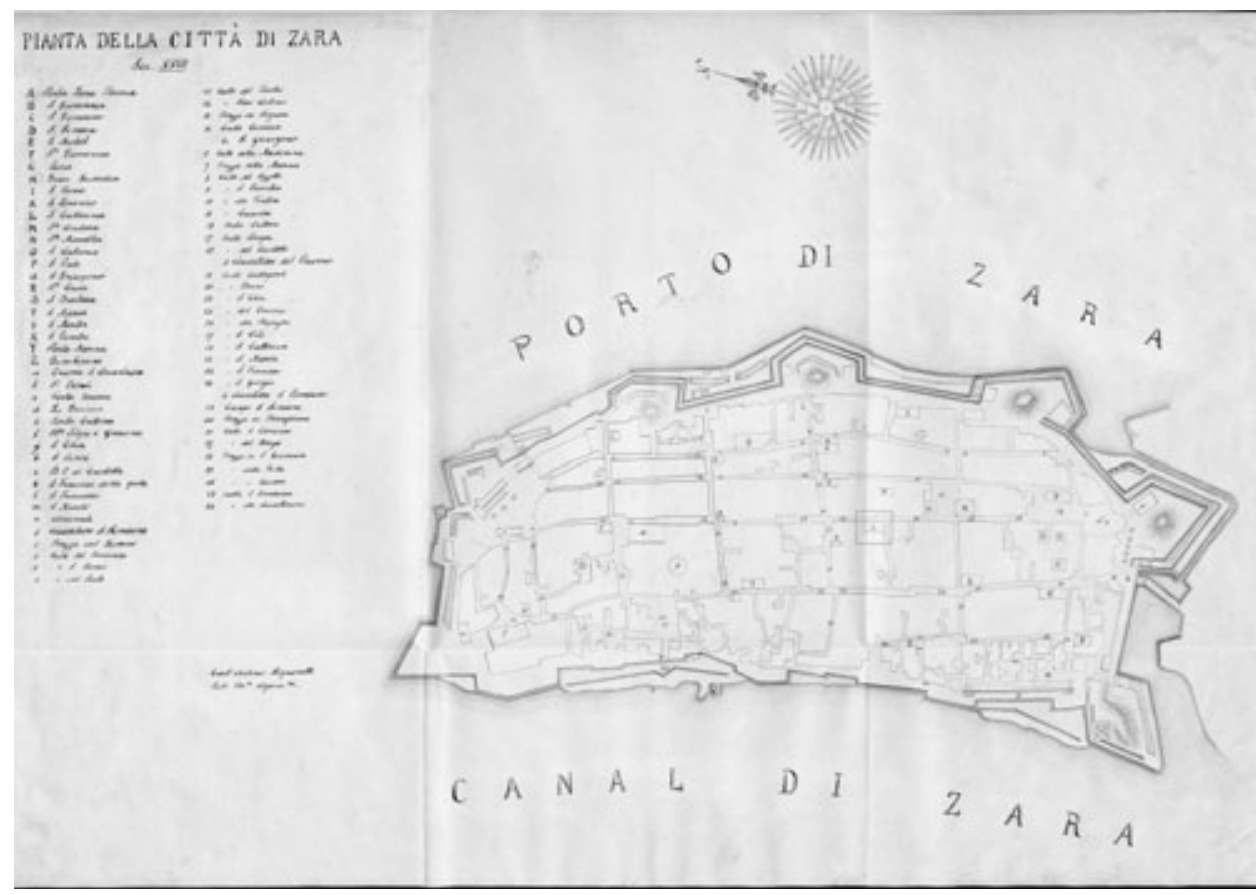

Slika 1. Na planu grada Zadra iz 18. stoljeća u crvenom kvadratu, pod slovom L, zabilježen je smještaj samostana i crkve sv. Katarine u Zadru. Izvor: Carlo Antonio Signoretti, Pianta della Città di Zara, sec. XVIII, ZKZD, sign. 25518, Ms. 698

Tomislav Raukar iznio je podatak da je zadarsko Tajno vijeće posebnom odlukom dopustilo Pelegrini de Saladinis 1388. godine da prepusti samostanu sv. Katarine posjede u

singulis, que infra, que infra predictos continentur confines et alios, si qui forent, accessibus et egressibus suis usque in uiam publicam et cum omnibus et singulis, que habet super se, intra se, infra se in integrum omnique iure et actione, usu seu requisitione sibi ex eo loco pro eo aut ipsi modo aliuquo pertinente, et hoc pro pretio et nomine pretti ducatorum vndecim cum dimidio auri. Tadija SMIČIKLAS, Codex diplomaticus regni Croatiae, Dalmatiae et Slavoniae (dalje: CD), vol. 17, Stjepan GUNJAČA (ur.), Zagreb, 1981., str. 431.

13 1414. 3 gennaro. Affittanza per anni 29 accordata dal monastero di san Grisogono al s(er) Lombardino q(uondam) Biaggio de Soppe di certe casette poste in confin di S. Catterina nova per l'annuo affitto di lire 32 pagabili nel giorno 25 decembre d'ogni anno. Šime LJUBIĆ, »Dva popisa listina glasovitoga manastira sv. Krševana u Zadru«, Starine, knj. 19, Zagreb, 1887., str. 140.

14 ....in confin di santa Catterina vicino alla piaza de signori. Isto, str. 147.

15 O plemićkoj obitelji Saladin vidi kod: S. DOKOZA - M. ANDREIS, Zadarsko plemstvo, str. 489-496. 
Petrčanima, i to pro victu monialium, što se doznaje iz njezine oporuke. ${ }^{16}$ Motivi Pelegrine Saladin o darivanju samostana sv. Katarine zasada ostaju nepoznati. ${ }^{17} \mathrm{~S}$ obzirom na to da je Pelegrina 22. svibnja 1392. godine oporučno ostavila imanje u Petrčanima, vrtove, maslinike u blizini Zadra i ostali zemljišni posjed u svom vlasništvu samostanu sv. Katarine, ${ }^{18}$ dakle četiri godine nakon odluke Tajnoga vijeća, može se pretpostaviti da je unutar te vremenske razdjelnice podignuta nova crkva u centru grada, a paralelno s njom i samostan. Naime, u raspravi oko pogrešne datacije oporuke Pelegrine Saladin u Diplomatičkom zborniku Kraljevine Hrvatske, Dalmacije i Slavonije za 1390. godinu, ${ }^{19}$ promaknula je spomenuta isprava od 2. travnja 1392. godine u kojoj je Pelegrina Saladin zabilježena kao utemeljiteljica i zaštitnica (fundatrix ac patrona) samostana sv. Katarine u Zadru. ${ }^{20}$ Riječ je o kupoprodajnom ugovoru zemljišne čestice uz crkvu samostana »nedavno podignutoga iz temelja « za potrebe njegove dogradnje, iz kojega je razvidno da je Pelegrina bila osobno uključena o tom poslu, sve do sastavljanja oporuke u poodmakloj dobi. ${ }^{21} \mathrm{U}$ oporuci je izrijekom navedeno da je Pelegrina ustanovila samostan za ženske redovnice iz građanskoga staleža. ${ }^{22}$ Stoga se kao službeni početak ženskoga benediktinskog samostana sv. Katarine u Zadru za građanke može uzeti 1392. godina, ${ }^{23}$ odnosno izvršenje oporuke utemeljiteljice i zaštitnice samostana Pelegrine Saladin, nakon njezine smrti u ljetu 1394. godine. ${ }^{24}$ Iste godine zabilježen je, moguće i prvi, kapelan novoga samostana sv. Katarine, svećenik glagoljaš Krševan pok. Drazoje iz Krbave. ${ }^{25}$

Bianchi je naveo da je samostan sv. Katarine proširen 1405. godine, ali da je nedugo potom izgorio te je zahvaljujući darovima građana ponovno obnovljen do 1414 . godine. ${ }^{26}$ Da je Bianchijev podatak o obnovi samostana točan, svjedoči spomen graditelja Franula pok. Dišana zvanoga Stravilo, koji je 1413. godine izvodio radove na crkvi sv. Katarine u Zadru. ${ }^{27} \mathrm{O}$ relativno čestim obnovama crkve svjedoče i zapisi iz oporuka. ${ }^{28}$ Zadarski

16 Tomislav RAUKAR, Zadar u XV. stoljeću. Ekonomski razvoj i društveni odnosi, Zagreb, 1977., str. 108, bilj. 22. O stvaranju zemljoposjeda zadarske plemićke obitelji Saladini vidi: Isto, str. 117-118.

17 Usp. N. JAKŠIĆ, »Osnutak franjevačkog samostana«, str. 351, 354.

18 I. OSTOJIĆ, Benediktinci u Hrvatskoj II, str. 90. O oporuci Pelegrine Saladin vidi više kod: Nikola JAKŠIĆ, »Osnutak franjevačkog samostana na Pašmanu 1392. godine«, Prilozi povijesti umjetnosti u Dalmaciji, god. 32, br. 1, Split, 1992., str. 351-355.

${ }^{19}$ Usp. Nikola JAKŠIĆ, »Kult sv. Petra u kasnoantičkom i srednjovjekovnom Zadru«, Scripta Branimiro Gabričević dicata, Josip DUKIĆ - Ante MILOŠEVIĆ - Željko RAPANIĆ (ur.), Trilj, 2010., str. 325, bilj. 65.

${ }^{20} \mathrm{CD}$, XVII, str. 431.

${ }^{21} \mathrm{U}$ tekstu njene oporuke zapisano je: ... licet infirmitate corporea et senio pregauata. CD, XVII, str. 287.

22 Item voluit et ordinauit supradictum monasterium sancte Katherine per ipsam testatricem fundari inceptum compleri debere per suos commissarios supradictos et in eo imponi et immitti debere moniales videlicet feminas populares, que habitent et habitare debeant in monasterio supradicto. CD, XVII, str. 289.

${ }_{23}$ Nakon te godine bilježe se oporučne ostavštine zadarskih građana u korist samostana sv. Katarine. Vidi: CD, XVIII, 505-506.

${ }^{24}$ Usp. N. JAKŠIĆ, »Osnutak franjevačkog samostana«, str. 352.

${ }_{25}$ Presbiter Cresiovanus q. Drasoy littere sclavonice capellanus monasterii Ste. Catherine... Petar RUNJE, Glagoljica u zadarskoj nadbiskupiji u srednjem vijeku, Zadar, 2005., str. 99, bilj. 388.

${ }^{26}$ C. F. BIANCHI, Zara Cristiana I, str. 443; C. F. BIANCHI, Fasti di Zara, Zara, 1888., str. 57, 61.

${ }^{27}$ N. KLAIĆ - I. PETRICIOLI, Zadar u srednjem vijeku, str. 516. Daniele Farlati navodi da je zadarski građanin Nikola Draperius 23. ožujka 1413. godine oporučno ostavio svoja dobra za proširenje samostana i crkve sv. Katarine. Daniele FARLATI, Illyricum Sacrum, vol. V, Venetiis, 1775., str. 21.

${ }_{28}$ Primjerice, 1450. godine Gašpar Longin pok. Jurja ostavio je in reparatione ecclesie Sancte Chatarine Monialium de Jadre 40 libara malih. HR-DAZD-31, Presbiter Thoma Tiscovaz (1448. - 1450.), b. unica, fasc. II, fol. 5r. 
arhiđakon Luka pok. Brajka oporučno je darovao 17. svibnja 1417. godine trećinu dijela svojih dobara raznim samostanima u gradu, a između ostalih i samostanu sv. Katarine. ${ }^{29}$ Tijekom kanonske vizitacije crkve sv. Katarine u Zadru 1517. godine, zapisano je da je ona bila u lošem stanju. Vjerojatno se u narednim godinama prionulo obnovi samostana jer se u oporukama navode legati na tu nakanu. ${ }^{30}$ Oko crkve bili su položeni vrtovi za koje je samostan plaćao naknadu Fiskalnoj komori u Zadru. ${ }^{31}$ Nije poznato jesu li ti vrtovi služili za potrebe samostana ili su davani u najam, ali je i u drugim komunama zabilježeno da su u samom gradu (intra murros) postojale male obradive zemljišne čestice. ${ }^{32}$

U prvoj polovini 16. stoljeća najbrojnije gradsko stanovništvo u Zadru pretežito je bilo hrvatskoga identiteta s obližnjih otoka i zaleđa, ${ }^{33}$ a taj je predznak nosio i samostan sv. Katarine. Ostojić je naglasio da redovnice sv. Katarine u to doba nisu poznavale talijanski jezik, pa im se moralo propovijedati hrvatski. Jednako, na hrvatskome se čitalo u koru, kapitulu i u blagovaonici živote svetaca i regulu sv. Benedikta. ${ }^{34}$ Štoviše, uz samostan sv. Katarine u Zadru vezan je postanak prvoga poznatog djela crkvene proze pisane hrvatskom latinicom pod naslovom Život ili legenda sv. Katarine, ${ }^{35}$ za koju je Vatroslav Jagić ustvrdio da predstavlja »čitav oficij koji su koludrice pobožno molile u slavu zavjetnice manastira svoga $\ll^{36}$. Razvidno je da su kapelani samostana bili svećenici glagoljaši i da se u crkvi sv. Katarine u Zadru glagoljalo. ${ }^{37}$ Uostalom, samostanske isprave, kao i otpisi mletačkih predstavnika vlasti tada su pisane i hrvatskim jezikom. ${ }^{38}$ Bianchi je naveo podatak da su 1591. godine svjetovne i crkvene vlasti u Zadru odredile da u samostane sv. Katarine

${ }^{29}$ Item uoluit, et ordinauit, quod omnia alia sua bona ressidua a legatis praedicta uendans, et praetium diuidas in tres partes aequales, quarum primam uoluit dari, et distribui Monasterio Sancti Grisogoni, Monasterio Sancte Marie, Monasterio Sancti Nicolai, Monasterio Sancti Dimitri, et Monasterio Sancte Catharine pro salteriis dicendi pro anima sua. HR-AZDN-18, Bonorum beneficiorumque, kut. 6, fol. 240.

${ }_{30}$ Primjerice, Jeronim iz Milana, prior hospitala sv. Martina u zadarskom Varošu, oporučno je ostavio 1523. godine po jedan dukat ženskim samostanima sv. Marije, sv. Dimitrija, sv. Nikole, sv. Katarine i sv. Marcele, a potom cijelu mjesečnu plaću koju je primao od bratovštine sv. Jakova u Zadru na ime službe priorata u visini od 86 lira pro fabrica monasterii Sancte Chatherine de Jadra. HR-DAZD-31, Marcus Aurelius Sonzonius (1513. - 1548.), b. unica, fasc. VI, br. 25.

31 HR-DAZD-31, Marcus Aurelius Sonzonius (1513. - 1548.), b. unica, Pars Visitationis Ecclesiarum Jadrae 1517, neozn. folija.

${ }^{32}$ Usp. Zoran LADIĆ, »Labinsko društvo u ranom novom vijeku u zrcalu bilježničkih dokumenata bilježnika Bartolomeja Gervazija«, Historijski zbornik, god. 61, br. 1, Zagreb, 2009., str. 61, bilj. 60.

${ }^{33}$ Usp. Domagoj MADUNIĆ, »Mjera grada: zadarski popis stanovništva 1527. godine«, Povijesni prilozi, vol. 28, br. 36, Zagreb, 2009., str. 55-57.

${ }^{34}$ I. OSTOJIĆ, Benediktinci u Hrvatskoj II, str. 92.

${ }^{35}$ N. KLAIĆ - I. PETRICIOLI, Zadar u srednjem vijeku, str. 350.

${ }^{36}$ Vatroslav JAGIĆ, »Ogledi stare hrvatske proze: Život sv. Katarine«, Starine, knj. I, Zagreb, 1869., str. 217. O tom proznom djelu vidi još: Dunja FALIŠEVAC, »Sveta Katarina - prva učena žena u hrvatskoj književnoj kulturi«, Slovo: časopis Staroslavenskoga instituta u Zagrebu, sv. 60, Zagreb, 2010., str. 255-277.

37 Primjerice, u tom svojstvu spomenut je početkom 16. stoljeća svećenik glagoljaš Šimun Sajković, koji je za izvršitelja oporuke od 17. svibnja 1520. godine imenovao svoga brata Anđela Sajkovića, monaha sv. Benedikta. Usp. P. RUNJE, Glagoljica u zadarskoj nadbiskupiji, str. 99-100; P. RUNJE »Knjige glagoljaša Zadarske nadbiskupije u srednjem vijeku«, Radovi Zavoda za povijesne znanosti HAZU u Zadru, sv. 49, Zadar, 2007., str. 180. O uporabi hrvatskoga jezika i glagoljice u crkvenim ustanovama u Zadru vidi opsežan rad: Ante Marija STRGAČIĆ, »Hrvatski jezik i glagoljica u crkvenim ustanovama grada Zadra«, Zadar Zbornik, Jakša RAVLIĆ (ur.), Zagreb, 1964., str. 373-429.

${ }^{38}$ Mand(at)o scritto in Illirico fatto dal S(igno)r Conte di Zara li 13 Lug(li)o 1513. ad inst(anz)a delle Monache di S(ant)a Catta(rina) p(er) le terre, che le med(esim)e comprarono, quali terre erano p(rim)a di Catichio Conte Paolo de Nouegradi. Hrvatska (dalje: HR) - Arhiv samostana sv. Marije u Zadru (dalje: ASSMZD), 
i sv. Marcele mogu biti primljene isključivo kćeri onih građana koji su bili članovi bratovštine sv. Jakova. ${ }^{39}$ Činjenica da su u samostan sv. Katarine ulazile djevojke iz građanskoga staleža, a u samostan sv. Marije i ostale ženske samostane u gradu isključivo kćeri iz plemićkih obitelji, ${ }^{40}$ odrazile su se očito i na historiografski interes o istraživanju prošlosti toga benediktinskog samostana u Zadru, što je razvidno iz nedostatka ciljanih znanstvenih radova o njemu. Ovim skromnim prilogom nastoji se prikazati dio njegove prošlosti.

\section{O posjedima benediktinki sv. Katarine prije mletačko-osmanskoga razgraničenja na zadarskome području 1576. godine}

Pri razmatranju ekonomskoga stanja crkvenih institucija u Zadru tijekom 16. stoljeća nužno je uzeti u obzir nepovoljne okolnosti koje su bitno utjecale na zemljoposjed u zadarskome okruženju. Ponajprije, to su bili mletačko-osmanski sukobi, koji su tijekom cijeloga 16. stoljeća uvjetovali, između ostaloga, agrarne odnose u zadarskom okružju, što se posljedično odražavalo na ekonomsko stanje crkvenih institucija. U izvornicima je upravo tijekom ratnih zbivanja zabilježen najveći broj zamolbi za izuzimanje plaćanja desetine zbog siromaštva redovničkih zajednica. ${ }^{41}$ Napose je samostan trpio tijekom mletačkoosmanskoga rata 1537. - 1540. godine. O tome se doznaje iz dopisa mletačkoga dužda Petra Landa od 12. veljače 1541. godine, upućenoga zadarskim rektorima knezu Marcantoniju de Mulli i kapetanu Alviseu Grittiju. Dužd je pozitivno odgovorio na zamolbe zadarskoga plemstva i građana da se samostani sv. Nikole, sv. Katarine i sv. Marcele oslobode plaćanja desetine jer u posljednjim četirima ratnim godinama nisu imale nikakvih prihoda. ${ }^{42}$ Uzroci tomu leže u činjenici da je zadarsko okružje bilo okupirano, a stanovništvo obližnjih naselja se preselilo unutar gradskih zidina te sudjelovalo u radovima oko fortifikacije grada, zbog čega su se zemljišni posjedi obrađivali rijetko i u reduciranom obimu, što je u konačnici rezultiralo nedostatkom pšenice i glađu u Zadru. ${ }^{43}$

Vrijedni podatci o posjedima ženskoga benediktinskog samostana sv. Katarine u Zadru pohranjeni su u Državnom arhivu u Veneciji. Samostanski zastupnik Nikola Ventura uputio je 29. listopada 1564. godine izvješće o prihodima i rashodima samostana na temelju kojega se

Monasterio di S. Cattarina 1599. Inventario de Beni di ragione del Monasterio di S. Cattarina (dalje: Inventario), fol. 22.

${ }^{39}$ C. F. BIANCHI, Fasti di Zara, str. 84. O bratovštini sv. Jakova u Zadru vidi rad: Maja NOVAK-SAMBRAILO, »Matrikula bratovštine sv. Jakova iz Galicije u Zadru«, Radovi Arhiva JAZU I, Zagreb, 1972., str. 5-31.

40 I. OSTOJIĆ, Benediktinci u Hrvatskoj II, str. 91.

${ }^{41}$ Primjerice, u ožujku 1539. godine, tijekom mletačko-osmanskoga rata, obratili su se mletačkom Senatu poslanici zadarske komune plemić Šimun Nassi te građani Antonio Nazzaro i Petar Valentić sa zamolbom da se ženske redovničke zajednice u Zadru zbog rata i siromaštva oslobode plaćanja desetine, čemu je Senat udovoljio. Italija - Archivio di Stato di Venezia (dalje: IT-ASVe), Senato. Deliberazioni Mar, Registri, r. 25, fol. $23 \mathrm{r}$.

42 Item si replica di gratia speciale che Vestra ?? uoglia remetter le decime alli poueri monasterii delle monache di Zara, perche sono anni quattro che non hanno intrada alcuna, et uiuono di elimossina et di quello che le poueri parenti le aiutano, et sano bene l'Eccellentissima $S$. V. che ogni di li sano inanti et quante elimosine a queste di San Nicolo, di Santa Catharina et di Santa Marcella ogni di li fanno. ... per esser ruinate le loro chiese et monasterii et le entrate loro consumate per la guerra passata. IT-ASVe, Sopraintendenti alle decime del clero, pezzo 39, Zara dal 1534 al 1583.

${ }^{43}$ Usp. IT-ASVe, Senato. Deliberazioni Mar, Registri, r. 25, fol. 22r-v; Tomislav RAUKAR - Ivo PETRICIOLI Franjo ŠVELEC - Šime PERIČIĆ, Zadar pod mletačkom upravom 1409. - 1797., Zadar, 1987., str. 247-250. 
određivao iznos crkvene desetine (decima) za pojedinu crkvenu ustanovu. Podatci prikazuju ekonomsko stanje samostana za razdoblje 1562. - 1564. godine, u relativno mirnodopskom razdoblju. U to doba samostanski prihodi mahom su pristizali od najmova i zakupa zemljišta (fiti et liuelli), a bila je riječ od oko 60 manjih čestica smještenih na području zadarskoga Varoša (in borgo di Zara). S obzirom da se tada prionulo izgradnji fortifikacije na području zadarskoga Varoša, ${ }^{44}$ te su zemljišne čestice nepovratno izgubljene a samostan je ostao bez tih prihoda, što ga je dodatno osiromašilo. ${ }^{45} \mathrm{Zbog}$ toga su redovnice doslovno preživljavale zahvaljujući pripomoći njihovih obitelji i milostinje vjernika ${ }^{46} \mathrm{Te}$ podatke potkrjepljuju i izvješća zadarskih nadbiskupa ad limina za isto razdoblje. ${ }^{47}$ Ipak, razvidno je da su do mletačko-osmanskoga razgraničenja 1576. godine na zadarskom području redovnice sv. Katarine posjedovale kako slijedi: posjed u Petrčanima (s četiri kolona), komad zemljišta u Kožinu (jedan kolon), posjed u Murvici, posjed u selu Buković (in Villa Bucouichi), za koje je naznačeno da je bilo pusto zbog posljednjega rata (la Villa uacua delli uillici dalla ultima guerra Turchesca), ${ }^{48}$ pa je te zemlje tada obrađivao samo jedan kmet iz drugoga sela (vilano d'altra villa), ${ }^{49}$ posjed u Vetereniću (Veterinichi) (jedan kolon), posjed na otoku Ugljanu (dva kolona) te posjed u Banju na otoku Pašmanu (jedan kolon). Sve ostale čestice bile su smještene, kako je naznačeno, u zadarskome Varošu i oko njega, u zadarskome polju te između Sukošana i Bibinja, ${ }^{50}$ odnosno u granicama nekadašnje zadarske astareje. Naznaka posjeda u Bukoviću i Vetereniću ${ }^{51}$ zanimljiva je u kontekstu rasprave o stjecanju i širenju samostanskih posjeda na hrvatskome teritoriju, ${ }^{52}$ tim više što je nazočnost hrvatskih knezova u samostanu sv. Katarine zabilježena u izvornicima iz 16. stoljeća. ${ }^{53}$

Nakon mletačko-osmanskoga razgraničenja 1576. godine Murvica, Buković i Veterenić ostali su na osmanskoj strani, a samostanska zemljišta nepovratno su izgubljena. ${ }^{54} \mathrm{U}$

${ }^{44}$ Usp. Andrej ŽMEGAČ, »Zadarske utvrde 16. stoljeća«, Radovi Instituta za povijest umjetnosti, br. 27, Zagreb, 2003. str. 107-118.

45 O siromašnom stanju samostana sv. Katarine zabilježeno je u izvješću apostolskoga vizitatora Agostina Valiera tijekom vizitacije Zadarske nadbiskupije 1579. godine: La miseria di questa pouera città per la perdita delli beni occupati nelle due prossime passate guerre dall tirannide del Turco natural nemico di questa Santa Sede, et specialmente il bisogno delli duoi Monasterii di monache n(ost)re che sono di Santa Catherina et di Santa Marcella. Italija, Archivio Apostolico Vaticano (dalje: IT-AAV), Congr. Vescovi e Regolari, Visita Ap. 78, Jadrensis, fol. 22v.

46 ...il quotidiano aiuto di nostri parenti, et le elemosine di pii et fedel christiani. IT-ASVe, Sopraintendenti alle decime del clero, Grauami dele monasterio di Santa Catherina di Zara, pezzo 39.

${ }^{47}$ Usp. Josip KOLANOVIĆ, »Zadarska nadbiskupija prema izvješćima ad limina 1599. - 1797.«, Sedamanaest stoljeća Zadarske crkve, sv. I., Livio MARIJAN (ur.), Zadar, 2009., str. 394-395.

48 Riječ je o Ciparskom ratu (1570. - 1573.).

49 Od 1499. do 1573. godine zamjetno je jačanje negativnih posljedica osmanskih ratova, od gospodarskih i demografskih pustošenja do prostornog sužavanja zadarskoga okružja. T. RAUKAR i dr., Zadar pod mletačkom upravom, str. 179.

${ }^{50}$ IT-ASVe, Sopraintendenti alle decime del clero, Zara. Monastero di S. Catherina di Zara, pezzo 39, br. 72.

${ }_{51}$ Tu su zabilježeni posjedi i hrvatskoga plemstva iz rodova knezova Krbavskih i Jamometa. Usp. Ivan MAJNARIĆ, Plemstvo zadarskog zaleđa u XIV. i XV. stoljeću, Zadar, 2018., str. 147-148.

${ }_{52} \mathrm{O}$ problematici stjecanja samostanskih posjeda u kasnom srednjem vijeku vidi kod: T. RAUKAR, Zadar $u$ $X V$. stoljeću, str. 106-108.

${ }^{53}$ Usp. Stephan Karl SANDER-FAES, Urban Elites of Zadar. Dalmatia and the Venetian Commonwealth (1540 - 1569), Roma, 2013., str. 195.

54 O razgraničenju vidi opširno kod: Ivna ANZULOVIĆ, »Razgraničenje između mletačke i turske vlasti na zadarskom području nakon ciparskog rata«, Zadarska smotra, god. 47, br. 1-3, Zadar, 1998., str. 53-150; Walter PANCIERA, »Building a Boundary: the First Venetian-Ottoman Border in Dalmatia, 1573-1576«, 
ispravama koje su bile pohranjene u samostanskom arhivu nekolicina ih se dotiče posjeda u Murvici. Zapisano je tako da je jedan od samostanskih prokuratora 1529. godine bio Mattio figlio di Marco da Zara Capo de Aruati (zapovjednik Hrvata). ${ }^{55}$ Broj redovnica u samostanu sv. Katarine u tom razdoblju bio je relativno velik (20), ${ }^{56}$ te se može zaključiti da je u gospodarskom smislu samostan stajao bolje do mletačko-osmanskih sukoba u 16. stoljeću, ${ }^{57}$ nego li kasnije kada taj opada zbog ratova, osmanskih provala i razvidnoga gubitka prihoda, da bi u 18 . stoljeću varirao između šest do osam redovnica. ${ }^{58}$ Taj zaključak proizlazi iz činjenice da su se redovito prihodi samostana kretali od 100 do 200 dukata na godišnjoj razini, prema čemu je u samostanu bilo dozvoljeno držati najviše 12 do 16 koludrica. ${ }^{59}$ Međutim, variranje broja redovnica u 16 . stoljeću može se povezati s problematikom nerezidiranja zadarskih nadbiskupa u gradu, što je razvidno iz dopisa zadarskoga plemićkog vijeća od 1551. godine, u kojemu se od mletačkih vlasti tražilo da »nadbiskup barem povremeno dođe rezidirati u Zadar radi posvete $\mathrm{i}$ oblačenja koludrica $\aleph^{60}$. Zanimljivo je da nije izostala ni reakcija zadarskoga građanskog staleža, koji je tomu pridodao opasku da »ako plemićki sinovi imaju pokoju djevojku za redovnički stalež, mi ih imamo puno više « ${ }^{61}$, što je potrebno razmotriti kroz optiku napetih odnosa i stalnih sukoba zadarskoga plemstva i građanstva u 16. stoljeću, ali i težnjom potonjih za boljim političkim pozicioniranjem u društvu. ${ }^{62}$ Upravo su građani Zadra, zbog edukativnoga i socijalnoga karaktera samostana sv. Katarine, dugo vremena darivali zadužbinu. ${ }^{63}$ Najčešće je bila riječ o oporučnim legatima, manjim novčanim

Radovi Zavoda za hrvatsku povijest Filozofskoga fakulteta Sveučilišta u Zagrebu, vol. 45, br. 1, Zagreb, 2013., str. 9-37.

55 Scrittura priuata fatta li 20 Feb(rai)o 1529., co(n) la quale Mattio figl(i)o di Marco da Zara Capo de Aruati, come Procu(rato)r delle Monache di S(ant) a Catta(rina) concede una sorte di terra posta in Villa Muruiça piccola a Giacomo Todorouich p(er) douer uenir li habitar p(er) l'ultimo di Giugno uenturo, come anco arar, et coltiuar tutta la d(ett) a sorte, et dar d'entrada quello li altri uillani, et p(ri)ma una quarta di formento a Natale, et una Lonza; Quando si fa il desinar alli Villani due galline, ma al tempo di far d(ett)a scritt(ur)a che darse un agnello, fatta co(n) carattere del sud(ett)o Procu(rato)r, e di due testimonij. In foglio di carta bombasina rosicata in parte da sarzi. HR-ASSMZD, Inventario, fol. 12. U spisima Zadarskoga kaptola spomenut je 1533. godine Marco de Marco Capo de Crouati. HR-AZDN-18, Liber privilegiorum, fol. 192.

56 D. MADUNIĆ, »Mjera grada«, str. 41.

${ }^{57}$ Godine 1559. i 1561. zabilježeno je u samostanu sv. Katarine 13 redovnica: opatica Isabetta Pasini te redovnice Ursa de Marchi, Skolastika Ventura, Magdalena Armani, Perina Pace, Bernardina Pasini, Ventura Ventura, Paulina Jordanić, Frančeska de Marchi, Donata Britaniko, Gabrijela Zapić, Rafaela Gislardi i Arkanđela Ventura. Nakon smrti opatice Isabette (Elizabete) Pasini, redovnice su glasovanjem na kapitulu 4. prosinca 1562. godine odabrale za novu opaticu samostana sestru Skolastiku Venturu. Usp. Hrvatska, Državni arhiv u Zadru, fond Bilježnici Zadra (dalje: HR-DAZD-31), Simon Mazzarellus (1555. - 1589.), b. I, fasc. IX, neoz. folija; HR-DAZD-31, Simon Budineus (1556. - 1599.), b. II, fasc. III, fol. 30-31; S. K. SANDER-FAES, Urban Elites of Zadar, str. 119.

${ }_{58}$ Nužno je uzeti u obzir da je ovdje riječ isključivo o broju redovnica, a ne o ukupnom broju stanovnica samostana. Usp. J. KOLANOVIĆ, »Zadarska nadbiskupija«, str. 396.

59 I. OSTOJIĆ, Benediktinci u Hrvatskoj II, str. 92.

${ }^{60}$...che l'Arciuescouo di Zara douesse uenire in questa Città a far residentia almeno per qualche tempo per uellare e sacrar alcune Monache. ASVe, Capi del Consiglio di dieci, Dispacci (lettere) dei rettori e pubblici rappresentanti, pezzo 283, br. 172 .

${ }^{61}$ La detta parte non men neccessaria a Citadini populari, che ad essi nobili: Quali se hano una loro figliola di vellare; noi altri n' habbiamo molto magior numero. IT-ASVe, Capi del Consiglio di dieci, Dispacci (lettere) dei rettori e pubblici rappresentanti, pezzo 283, br. 175.

${ }^{62}$ Usp. T. RAUKAR i dr., Zadar pod mletačkom upravom, str. 270-271.

${ }^{63}$ I. OSTOJIĆ, Benediktinci u Hrvatskoj II, str. 92. 
iznosima ili prijenosu livela gradskih nekretnina. Njihov cjelovit popis, kao i uprihođen iznos za drugu polovicu 16. stoljeća zapisao je prokurator Ventura. ${ }^{64}$ Usto je, samostan posjedovao stočni fond o kojemu su brigu vodili čuvari stoke (brauari) na pašnjacima u okolici grada i na zadarskim otocima. ${ }^{65} \mathrm{Ipak}$, okosnicu gospodarskoga poslovanja činio je zemljoposjed, što je uostalom vrijedilo za gotovo sve crkvene institucije u Zadru u razmatranome razdoblju. ${ }^{66}$

Zbog čestih promjena najamnika te zamjene i prodaje zemljišta nije moguće precizno pratiti ritam stjecanja, odnosno zamjenu ili gubitke tih posjeda. Usto su pojedini posjedi u blizini istih naselja naznačeni različitim toponimima pa se ne može sa sigurnošću utvrditi je li riječ o istovjetnim zemljišnim česticama. Primjerice, zadarski građanin ser Petar Venturin zvani Pezelj prodao je 1534. godine polovinu od sedam gonjaja vinograda na zemlji samostana sv. Katarine na položaju Zloušane između sela Bibinja i sela Sukošana majstoru Pavlu de Boycu, ${ }^{67}$ što je zabilježeno i u inventaru spisa samostana sv. Katarine. ${ }^{68}$ Godine 1575. zabilježeno je da su koludrice sv. Katarine dale u najam mladi vinograd na području Zloušana. ${ }^{69}$ Zloušane su današnji položaj na sjeverozapadu Sukošana, uz more, a u izvorima se ponekad iskazuju i kao Malo Bibinje, za koje je u popisu stanovništva iz 1527. godine zapisano da imaju 49 stanovnika. ${ }^{70} \mathrm{U}$ Venturinu izvješću spomenut je posjed »in Gladussa in confini del Bibigne de gognali 24 aratoria et oliuata in parte lauorati per li Vilani di S(an) Cassan numero $6 «^{71}$. Pretpostavka je da je riječ o položaju na samostanskom posjedu u Zloušanima, ali se dopušta i druga mogućnost. U svakom slučaju, nakon Ciparskoga rata (1570. - 1573.) i mletačko-osmanskoga razgraničenja 1576. godine osjetno se smanjuju posjedi benediktinskoga samostana sv. Katarine u Zadru.

${ }^{64}$ IT-ASVe, Sopraintendenti alle decime del clero, Zara. Monastero di S. Catherina di Zara, pezzo 39, br. 72.

${ }^{65}$ HR-ASSMZD, Libro delle monache de Santa Catarina, sv. 2, fol. 164v-165r.

${ }^{66}$ Usp. L. ČORALIĆ, »Zemljišni posjedi dominikanskog samostana u Zadru u XVII. i XVIII. stoljeću«, str. 214

${ }^{67}$ Ser Petrus de Ventura dictus Pesegl ciuis, et habitator Iadre sponte et libere per se suosquem heredes et sucesoris dedit cessit et renunciauit magistro Paulo de Boyco cerdoni ibidem presentem pro se et heredibus suis acceptanti omnia iura et actiones que et quas habet et habere uident in medietante gonaioris septem uel circa capitum vinearum positis in loco Slousane inter villis Bibine et villis Sancti Cassiani super terreno Venerabili Dominarum monialium Sancte Catherine de Iadra pro indiuiso cum alia medietatae cum dicto cessionario... - i to za cijenu: pro pretio et nomine pretii librarum centum et triginta paruorum... HR-DAZD-31, Augustinus Martius (1533. - 1552.), b. unica, f. I, 1534. Zahvaljujem kolegici Ivni Anzulović na ustupljenom podatku.

${ }^{68}$ HR-ASSMZD, Inventario, fol. 44.

${ }^{69}$ Scritt(ur)a fatta li 18 Feb(rai)o 1575 dal S(igno)r Gio(uanni) Giac(om)o Zappich Procu(rato)r delle d(ett) e Monache, qualm(en)te le med(esim)e concedono li capi di uiti essitenti a Zlousane nelle pertinenze tra la Villa di S(an) Cassan et Bibigne sopra il ter(ren)o d'esse Monache, p(ri)ma hauuti da Cicho di Nicolo Godouich, et di Perocha, et altri, et ciò p(er) rinouarli co(n) pastino a Michel Gollisich, et a Zuane Smolich habitanti in S(an) Cassan, col corrisponder p(er) l'an(n)o sud(ett)o la metà così de uiti, come d'oliuari, e nell'euenire il quarto di tutto. HR-ASSMZD, Inventario, fol. 36.

${ }^{70}$ Ivna ANZULOVIĆ »Crkva sv. Marije od Duba ili Stublja, njezin položaj i srednjovjekovna sela na području nekadašnjeg Obrovca jugoistočno od Zadra«, Diadora, sv. 22, Zadar, 2007., str. 325.

${ }^{71}$ IT-ASV, Sopraintendenti alle decime del clero, Zara. Monastero di S. Catherina di Zara, pezzo 39, br. 72. 


\section{Inventar posjeda i spisa samostana sv. Katarine u Zadru iz 1599. godine}

Samostanski arhivi su s osobitom pozornošću čuvali spise, darovnice i ostale isprave u prvom redu vezane uz sam samostan, njegove interese i napose zemljišne posjede, koji su činili okosnicu gospodarske interakcije gotovo svih crkvenih institucija u razmatranom razdoblju. Razne nepovoljne okolnosti poput ratova, požara, mogućih nepogoda, ali ponekad i nedovoljne brige o crkvenim arhivima u nepovrat su odnijele vrijedne isprave. Ono što je sačuvano, pa makar i u inventarskom obliku, vrijedno je istražiti, analizirati i valorizirati korektnom interpretacijom, što je preduvjet objektivnoga sagledavanja povijesnih datosti, u ovom slučaju ekonomskoga stanja crkvenih institucija u Zadru, tim više što inventari obiluju podatcima za bolje razumijevanje onomastičkih i toponomastičkih datosti određenoga područja. ${ }^{72}$

Inventar posjeda ženskoga benediktinskog samostana sv. Katarine spomenuo je Seid M. Traljić u radu o vodenim znakovima u rukopisima i ispravama samostana sv. Marije u Zadru. ${ }^{73} \mathrm{Na}$ početnoj foliji inventara zapisano je da ga je »1. rujna 1599 . godine, u vrijeme Presvijetloga Monsignora Minuccija Minuccija, ${ }^{74}$ plemića iz Seravale, cijenjenoga zadarskog nadbiskupa, doktora obaju prava, i njegova generalnog vikara doktora Ivana Grisogona, ${ }^{75}$ dok je opatica samostana sv. Katarine bila s. Arkanđela Ventura sastavio Bartol Loccadello, pisar samostana.« Loccadello je zapisao »sva zemljišta i posjede koje monahinje posjeduju, imaju i uživaju « ${ }^{76}$.

Prvi zapis sastavio je pisar o kuli i utvrdi (torre e chastello), koje je samostan posjedovao u Petrčanima, nella luor Villa, dakle na samostanskom posjedu, na kojem su živjeli i obrađi-

${ }^{72}$ Vidi primjerice radove vezane za crkvene institucije u Zadru: Stanko Josip ŠKUNCA, »Inventar spisa samostana sv. Nikole sestara klarisa u Zadru«, Radovi Zavoda za povijesne znanosti HAZU u Zadru, br. 49, Zadar, 2007., str. 185-204; Lovorka C̆ORALIĆ, »Zemljišni posjedi dominikanskog samostana u Zadru u XVII. i XVIII. stoljeću«, Croatica christiana periodica, vol. 18, br. 33, Zagreb, 1994., str. 213-224; Pavo ŽIVKOVIĆ, »Posjedi i prihodi samostana svetog Krševana u Zadru od osnivanja do konca XV. stoljeća«, 1000. godina samostana Sv. Krševana u Zadru, Ivo PETRICIOLI (ur.), Zadar, 1990., str. 109-129; Eduard PERIČIĆ, »Samostan svete Marije u Zadru od njegova osnutka do danas«, Kulturna baština samostana sv. Marije u Zadru, Grga NOVAK - Vjekoslav MAS̆TROVIĆ (ur.), Zadar, 1968., str. 7-59.

${ }^{73}$ Seid M. TRALJIĆ, »Vodeni znakovi u dokumentima i rukopisima samostana svete Marije u Zadru«, Kulturna baština samostana sv. Marije u Zadru, Grga NOVAK - Vjekoslav MAŠTROVIĆ (ur.), Zadar, 1968., str. 269-270.

${ }^{74}$ Upravo je zadarski nadbiskup Minuccio Minucci (1596. - 1604.) na tragu posttridentske obnove pokrenuo reformu zadarskih samostana. Naime, samostani su dekretima Tridentskoga sabora bili izuzeti od biskupske vlasti i podvrgnuti izravno Papinom autoritetu. Minucci je ishodovao kod mjerodavnih crkvenih vlasti da mu se dodijeli ovlast nad zadarskim samostanima. Samostani su se našli u središtu njegove reforme jer ih je osiromašeno zadarsko plemstvo držalo kao socijalne ustanove, a tek onda pobožna središta, u koje je nastojalo zbrinuti njihove kćeri koje, zbog siromaštva, nije moglo opremiti za udaju. Prema J. Vrandečiću, na taj način su samostanski ležaji postali prostorom nadmetanja lokalne elite u kojoj su se najjače plemićke kuće borile za prevlast. Zanimljiva je opaska zadarskoga nadbiskupa Minuccija kojom je zadarske redovnice opisao kao brojne, ali nepokorne i teške za vladanje. Josip VRANDEČIĆ, Zadarski nadbiskup Minuccio Minucci $i$ njegova jadranska misija, Zagreb - Split, 2017., str. 150-151.

${ }^{75}$ Ivan Grisogono bio je pripadnik staroga i nekoć bogatoga zadarskog plemstva nazvanoga po gradskome zaštitniku sv. Krševanu (Grisogonus), koji je, osim nadbiskupa Minuccija, jedini u Zadru u to doba posjedovao doktorat iz prava. Zbog njegove učenosti, dobrote i uslužnosti zadarski nadbiskup Minuccio Minucci imenovao ga je svojim vikarom, unatoč činjenici da je bio laik. J. VRANDEČIĆ, Zadarski nadbiskup Minuccio Minucci, str. 147.

${ }^{76}$ HR-ASSMZD, Inventario, neozn. folija. 
vali samostanska zemljišta petrčanski koloni. Riječ je o troškovniku od 1. kolovoza 1589. godine, kada su koludrice započele s izgradnjom kule i utvrde, a radovi su dovršeni 15. svibnja 1590. godine, za što je bilo utrošeno 365 lira. ${ }^{77} \mathrm{U}$ računskim knjigama samostana sv. Katarine zabilježen je isti troškovnik, ali s tom razlikom da je u naslovu naznačeno kako je riječ o kaštelu i utvrdi u Kožinu. ${ }^{78} \mathrm{~S}$ obzirom na to da su podatci o troškovima gradnje kaštela iz samostanskog inventara identični podatcima iz računskih knjiga, vjerojatno je riječ o pogrešno upisanom imenu naselja. ${ }^{79}$

Radove na izgradnji kule i utvrde u Petrčanima izvršili su majstori Trifun Trifunić ${ }^{80}$ i Lovro pok. Jakova (Jacchometto). Iako nije naznačena točna veličina utvrde s kulom, o njezinu opsegu donekle govori podatak da su građevinari prilikom izgradnje utrošili 1500 komada krovnoga crijepa. Ostatci kule i gospodarskih zgrada s obrambenim zidom (revelinom) vidljivi su i danas u Gornjim Petrčanima, a na mjestu nekadašnje kule sagrađena je u 20. stoljeću obiteljska kuća. Riječ je o kvadratnom zdanju, koji je služilo za obranu i stanovanje, po uzoru na komunalne utvrde - stražice na zadarskome kopnenom posjedu. ${ }^{81}$ Motiv izgradnji utvrde i obrambenoga zida treba tražiti u stalnoj opasnosti od osmanskih provala u to vrijeme, ${ }^{82}$ ali i u činjenici da je, sudeći prema relaciji zadarskoga kapetana Lorenza Coccoa iz 1581. godine, u njima stanovala tek nekolicina seljana, a zidine oko naselja bile su u lošem stanju, zbog čega je kapetan Cocco zaključio da bi u slučaju rata pri prvom naletu ona bila izgubljena. ${ }^{83} \mathrm{O}$ važnosti kula posvjedočio je mletački sindik Andrea Giustinian 1576. godine, koji je upozorio „kad bi se vratila natrag zemljišta bez kula, nitko se ne bi usudio da ih obrađuje, pa i kad bi uistinu bilo ljudstva $\ll^{84}$.

77 Isto.

${ }^{78}$ HR-ASSMZD, Libro delle monache de Santa Catarina, sv. 2, fol. 266v.

${ }^{79}$ Čini se da je u Kožinu u nepoznato vrijeme ipak postojala utvrda. U fondu knjižnice Correr u Veneciji pohranjen je prijepis relacije Alvisea Moceniga s početka 18. stoljeća pod naslovom Descrizione del Territorio di Zara u kojemu je navedeno da su se naselja Glupavci (Gornje Petrčane), Kožino i Sv. Bartul nazivali skupnim imenom Tri kaštela (Le tre Villette di Glupaucci, Cosino e S. Bortolomeo, che con una sol uoce sono tutte tre dette li 3 Castelli). IT-BCMC, Cod. Cicogna, 2074, neozn. folija.

${ }^{80}$ Moguće je da je riječ o odvjetku graditeljske obitelji Trifunić. Ivan Trifunić zabilježen je u literaturi kao graditelj renesansnoga klaustra samostana sv. Frane u Zadru 1556. godine. Cvito FISKOVIĆ, »Zadarska renesansna crkva sv. Marije«, Prilozi povijesti umjetnosti u Dalmaciji, god. 10, br. 1, Split, 1956., str. 120.

${ }^{81}$ Vidi rad: Franjo SMILJANIĆ, »Jesu li komunalne utvrde - stražice na zadarskom komunalnom kopnenom posjedu doista kasnoantičke«, Vjesnik Arheološkog muzeja u Zagrebu, god. 43, br. 1, Zagreb, 2010., str. $399-413$.

${ }^{82} \mathrm{O}$ osmanskim upadima na zadarsko područje vidi: Seid M. TRALJIĆ, »Zadar i turska pozadina od XV. do potkraj XIX. stoljeća«, Grad Zadar. Presjek kroz povijest, Grga NOVAK - Vjekoslav MAŠTROVIĆ (ur.), Zadar, 1966., str. 203-227. Zanimljivo je da su u 16. stoljeću na otoku Bapcu koloni zemljoposjednika de Soppe, koji su imali zemljišne čestice između Kožina i Petrčana u to vrijeme, izričito tražili da se sagrade obrambene zidine oko dvorišta kako bi se zaštitile njihove kuće, što zorno govori o strahu koji je vladao zbog Osmanlija, čak i na relativno sigurnijim otocima. Sofija SORIĆ, »Utvrđeni ljetnikovac obitelji de Soppe na Bapcu«, Radovi Zavoda za povijesne znanosti HAZU u Zadru, sv. 50, Zadar, 2008., str. 52. Strah od Osmanlija utjecao je u prvoj polovini 16. stoljeća na opseg zemljoradnje u zadarskom okružju. Usp. D. MADUNIĆ, »Mjera grada«, str. 31, bilj. 24.

${ }^{83}$ Grga NOVAK, Commissiones et Relationes Venetae, vol. IV (1572. - 1590), Monumenta spectantia historiam Slavorum Medridionalium, sv. 47, Zagreb, 1964. (dalje: Commissiones IV), str. 375

${ }^{84}$ Vicko SOLITRO, Povijesni dokumenti o Istri i Dalmaciji, Split, 1989., str. 111. V. Solitro u svom je radu pogrešno naveo da je riječ o relaciji Antuna Giustiniana iz 1575. godine. Relaciju potpisuje mletački sindik Andrea Giustinian 1576. godine, koji je tu službu vršio zajedno s Ottavianom Valierom od 1575. godine. Vidi popis mletačkih dužnosnika u Dalmaciji: IT-Biblioteca del Civico Museo Correr (dalje: BCMC), Cod. Cicogna, 2074, fol. 1v. Usp. Commisiones et Relationes IV, str. 176; Emma MAGLIO, »Circolazione e diffusione 
S obzirom na položaj kule iznad agrikulturne zone (podvornice i polja u vlasništvu samostana), može se pretpostaviti da su osim obrambene i stambene funkcije te kule i utvrde imale i funkciju obilježavanja granica pojedinih posjeda, kao jamstvo njihove sigurnosti. ${ }^{85}$ Nakon izgradnje kule i utvrde u Petrčanima mjernik Kristofor Ventura prionuo je 15. svibnja 1590. godine izmjeri svih nastambi i zemljišta samostana sv. Katarine na rečenome posjedu (villa). ${ }^{86}$

Na samostanskome posjedu u Petrčanima tada su zemlju obrađivala šestorica kolona, zajedno s obiteljima: Ivan Paić, Ivan Milutinović, Mate Diklić, Ivan Čačinović, Petar Devenešić (de Venesich) i Mate Pavić. Riječ je o obiteljima koje su na popisima stanovništva iz 1608. i 1610. godine navedene na području Gornjih Petrčana (Glupavac), što potvrđuje da se tu nalazila Villa, odnosno selo u posjedu samostana benediktinki sv. Katarine. ${ }^{87}$ Čini se da su se petrčanski koloni, moguće tijekom Ciparskoga rata $(1570 .-1573.){ }^{88}$ povukli u zadarsku Varoš. ${ }^{89} \mathrm{U}$ prilog tomu idu dvije relacije. Prvu iz 1576. godine potpisuje mletački sindik za Dalmaciju Andrea Giustinian. Opisujući Zadar i njegovu utvrdu on je naveo: „Odjahao sam sve do granice koju sada uživamo (granica s Osmanlijama, op. a.), koja je samo tri milje daleko od grada, i budući da su razorena sva obitavališta, jadni seljaci moraju svake večeri doći sa svom svojom stokom u grad te svakog jutra ići vani u polje i raditi uvijek praćeni od dviju četa stradiota. ${ }^{\text {"90 }}$ Druga je ona zadarskoga kneza Zuan Battiste Michielija od 27. ožujka 1586. godine u kojoj je navedeno da su nakon rata ponovno naseljeni Diklo, Petrčane (Gornje) i Portoschiauina (Donje Petrčane), ${ }^{91}$ ali i činjenica da su same mletačke vlasti u Zadru tijekom osmanskih provala pozivale stanovništvo na povlačenje iz ugroženih područja. ${ }^{92}$ Tako je zapisano da je jedan od spomenutih kolona Ivan Paić, sin Jurja, oženio 1576. godine Maricu kći Franje Travisana, u kući Bare pekara blizu fratara sv. Ivana u zadarskome Varošu. ${ }^{93} \mathrm{U}$ matičnim knjigama vjenčanih župe sv. Stošije

dei disegni di fortezze in area mediterranea «, Leonardo e il Rinascimento nei Codici napoletani: Influenze e modelli per l'architettura e l'ingegneria, Alfredo BUCCARO - Maria RASCAGLIA (ur.), Napoli, 2020., str. 618.

${ }^{85}$ Usp. Josipa BARAKA PERICA - Nikša GRBIĆ, »Rezultati istraživanja utvrde Ošlje-Gradac i selo Ošlje u općem povijesno-arheološkom kontekstu«, Anali Zavoda za povijesne znanosti HAZU u Dubrovniku, br. 57, Dubrovnik, 2019., str. 171.

${ }^{86}$ HR-ASSMZD, Inventario, neozn. folija.

${ }^{87}$ Usp. Roman JELIĆ, »Stanovništvo kopnenog dijela zadarskog područja 1608. i 1695.«, Zadarska revija, god. 34, br. 6, Zadar, 1985., str. 555-573; Zdenko DUNDOVIĆ, »Popis stanovništva kopnenog dijela zadarskog okružja iz 1610. godine«, Radovi Zavoda za povijesne znanosti HAZU u Zadru, br. 61, Zadar, 2019., str. 294.

${ }^{88}$ Seid M. Traljić naveo je da je u vrijeme rata 1571. godine zadarski delegat Petar Fanfogna predlagao Vijeću desetorice u Mlecima da se zbog nedovoljnih fortifikacija u Zadru otruju sve vode u njegovu kotaru pa $\mathrm{i}$ Vransko jezero te zaključio da ,iz ovoga izlazi da je mletački posjed u zadarskom kotaru morao biti pust, dok se iznosi ovakav prijedlog“. S. M. TRALJIĆ, »Zadar i turska pozadina«, str. 211. O intenzivnim osmanskim prodorima na zadarsko i ninsko područje 1570. godine vidi više kod: T. RAUKAR i dr., Zadar pod mletačkom upravom, str. 218-220.

${ }^{89} \mathrm{U}$ ispravama samostana sv. Katarine i u drugim izvornicima zabilježene su česte gospodarske interakcije između benediktinki sv. Katarine i zadarskih Varošana, pretežito težaka. Usp. Zdenko DUNDOVIĆ, Bratovština zadarskih Varošana, Zadar, 2020., str. 184.

90 V. SOLITRO, Povijesni dokumenti o Istri i Dalmaciji, str. 111.

${ }^{91}$ Commissiones $I V$, str. 375.

92 T. RAUKAR i dr., Zadar pod mletačkom upravom, str. 183.

${ }_{93}$ Hrvatska - Arhiv Zadarske nadbiskupije - Zbirka matičnih knjiga i parica matičnih knjiga Zadarske nadbiskupije 156./2010. (dalje: HR-AZDN-43), Zadar - Sv. Stošija, Matrimonium I (1576. - 1593.), fol. 31r. 
u Zadru zabilježena su u drugoj polovini 16. stoljeća prezimena pripadnika obitelji Diklić, Čačinović i Devenešić (Venešić). ${ }^{94}$ Napuštanje selišta zbog straha od osmanskih provala nije bilo strano tijekom cijeloga nesigurnog 16. stoljeća, o čemu svjedoče i pojedini kolonatski ugovori. ${ }^{95} \mathrm{Uz}$ to, zanimljivo je da nijedno od spomenutih naselja, uključujući Kožino, nije vizitirano tijekom apostolske vizitacije 1579. godine, za razliku od apostolske vizitacije 1603. godine. ${ }^{96}$

K tomu, na području između Petrčana i Kožina dolazilo je do lokalnih migracija stanovništva ovisno o kolonatskim ugovorima s različitim zemljoposjednicima na tom području, odnosno u blizini susjednih naselja. ${ }^{97} \mathrm{U}$ prilog tomu navodi se da je početkom 17 . stoljeća u Kožinu bilo pet domaćinstava Velanovića, ${ }^{98}$ a poznato je da su Velanovići početkom 16. stoljeća živjeli u Petrčanima, a obrađivali zemljišta samostana sv. Marije u Kožinu. ${ }^{99}$ Jednako, Velanovići su zabilježeni 1534. godine i u Poličniku. ${ }^{100}$ Slično je s prezimenom Marojić, koje je sredinom 16. stoljeća zabilježeno u Kožinu u kontekstu najma samostanskoga zemljišta sv. Katarine, ${ }^{101}$ a početkom 17. stoljeća u Bokanjcu i na Puntamici, ${ }^{102}$ iako ishodište prezimena treba tražiti u Bokanjcu. ${ }^{103}$ Koncem 17. stoljeća zapažene su u ugovorima i migracije stanovništva iz udaljenijih naselja u Petrčane. ${ }^{104}$

${ }^{4}$ Vidi rad: Roman JELIĆ, »Stanovništvo Zadra u drugoj polovici XVI. i početkom XVII. stoljeća gledano kroz matice vjenčanih«, Starine, knj. 49, Zagreb, 1959., str. 349-509.

95 Primjerice, 5. srpnja 1559. godine sklopio je samostan sv. Krševana u Zadru ugovor s Nikolom Mandićem (Mandecalouich) iz Dikla o najmu tri ždrijeba zemlje in pertinentiis dictae uillae Diclo ... terreni arratorii contiguae ecclesiae Sancti Martini de dicta uilla ad uallem dictam Duorniccha Draga. Uz redovite uvjete najma u ugovoru je zapisano da oni ne obvezuju najmitelja u slučaju osmanskih provala i rata: ...quod si quo casu quod absit infra tempus huius affictus incursione Turcharum siue bello totta uilla Diclo omnibus habitatoribus destituta remaneret, et ex ea omnes fugarentur in hoc casu conductor suprascriptas non teneatur soluere quicquam Dominis fundi. Nužno je zamijetiti da je spomenut bijeg stanovnika iz Dikla u slučaju rata, što se moguće već bilo dogodilo tijekom mletačko-osmanskoga sukoba 1537. - 1540., što potkrepljuje i daljnji tekst u kojem se navodi da ugovorne obveze, ako bi se zemljište dalo obrađivati, obvezuju najmitelja nakon završetka rata. Taj zaključak osnažuju i izvješća mletačke vlade iz 1538. godine, da su se u gradu tada nalazili mnogi seljaci koji su pobjegli s terraferme. Usp. HR-DAZD-31, Simon Budineus (1556. - 1599.), b. I, fasc. II, fol. 189v; T. RAUKAR i dr., Zadar pod mletačkom upravom, str. 240.

96 Apostolski vizitator Michele Priuli vizitirao je 30. travnja 1603. godine crkvu sv. Ivana i Pavla u Petrčanima, koja je u to vrijeme bila kapelanija župe Kožino (...in Villa Peterzane seu dicitur de Porto Schiauina et est membrum Villae et Parrochiae Cosinoselo), koju je također vizitirao. IT-AAV-Visit. Eccles. Dalmat., Jadrensis, Miscellanea Armad. VII, vol. 101, fol. 948r, 950r.

${ }_{97}$ Usp. T. RAUKAR i dr., Zadar pod mletačkom upravom, str. 251-254.

98 Usp. Z. DUNDOVIĆ, »Popis stanovništva«, str. 293.

99 1507. 27. febraro, per il monasterio di santa Maria, concession à pastinar alli Tomaso Villanouich e Juraj Gregoricich, ambi da Peterzane, di gognali 3 di terreno posto in villa Stocosino Sello con sopra 10 stesso terreno 18 oliueri al terzo, e di altri 4 gognali posti in detta villa al $4^{\text {to }}$. Stjepan GUNJAČA, »Repertorium actuum domini Antonii de Zandonatis olim publici et iurati notarii Iadre«, Starine, sv. 42, Zagreb, 1949., str. 309.

${ }^{100}$ Tada je zabilježen Donato Vellanouich de Polesnich. Ivna ANZULOVIĆ, »O opstojnosti hrvatskog pučanstva sjeverne Dalmacije iz predturskog vremena«, Zadarska smotra, vol. 47, br. 4-6, Zadar, 1998., str. 295.

${ }^{101}$ HR-DAZD-31, Simon Budineus (1556. - 1599.), b. I, fasc. II, fol. 63v.

${ }^{102}$ Usp. Z. DUNDOVIĆ, »Popis stanovništva«, str. 274

${ }^{103}$ Vidi oporuku Mate Marojića pok. Luke iz Bokanjca iz 1567. godine. HR-DAZD-31, Simeon Turino (1577. - 1584.), b. II, fasc. VI, br. 2.

${ }^{104}$ Primjerice, iz spisa u fondu samostana sv. Krševana u Zadru od 11. lipnja 1696. godine doznaje se da je zbog obrađivanja samostanskih zemljišta u Petrčanima doselio iz Ražanca Jure Peršić (Zorzi Persich da Razanzse, habitante di nuouo a Peterzane), a koji je početkom 18. stoljeća u ispravama naznačen kao Zorzi Persich da Peterzane. HR-DAZD-336, Benediktinski samostan sv. Krševana Zadar (918. - 1806.), kut. 6, fasc. 2.3.6.17, br. 52/3. 
Nazočnost Devenešića u Petrčanima zabilježena je i ranije. U kupoprodajnome ugovoru od 12. ožujka 1567. godine spomenut je »Antonio de Venesich habitatori Villae Peterzane«, koji je kupio ograđeni vinograd »positum in pertinentis dictae Villae super terreno ser Vincentii Hmelcouich et fratris « ${ }^{105}$. Petar Devenešić oženio je 1594. godine u crkvi Gospe od Zdravlja u Zadru Margaretu kći majstora Marka Zomera (?). ${ }^{106}$ Za pripadnike obitelji Milutinović u izvornicima se navodi da su bili iz Stomorina sela, a sredinom 16. stoljeća imali su nastambe u gradu. ${ }^{107}$ No, u izvornicima su spomenuti i u selima Starošane i Miljacka (Starosane; Migliazcha), ${ }^{108}$ što upućuje na zaključak da su migracije kolona uslijed osmanskih provala u to doba bile učestale u zadarskome okružju. Do danas se, koliko je poznato, u Gornjim Petrčanima očuvalo samo prezime Diklić, ${ }^{109}$ a prezime Pavić u Petrčanima i Kožinu.

S obzirom na prostorni smještaj sela na prisojnoj strani brda, kojemu se sa SI protezalo krševito tlo i šuma, a JZ, prema suncu, spuštalo se polje, može se u ovom slučaju primijeniti zaključak I. Anzulović da takav smještaj nastambi odgovara smještaju vila rustika, koje su uvijek bile uz rubove posjeda, tj. polja na nešto povišenu položaju, na kojemu su onda nastajale aglomeracije srednjovjekovnih sela, nastavljajući tako na tim položajima kontinuitet života. ${ }^{110}$ Do danas su u Gornjim Petrčanima vidljivi ostatci tih nastambi u nizu, ispod kojih se nalaze vrtovi. Iako u literaturi nema ciljanih radova o stambenoj gradnji seoskih nastambi u 16. stoljeću na zadarskom području, razvidno je da su te nastambe građene sličnom tehnikom poput onih gradskih, u manjem obimu. ${ }^{111}$ Riječ je, zapravo, o organizaciji seoskoga kućanstva gdje sklop kuća čini zatvoreno ili poluza-

\footnotetext{
${ }^{105}$ Najvjerojatnije je riječ o zemljištu obitelji Hmeljković u blizini današnjih Donjih Petrčana dijelom pod vinogradima, a dijelom pod oranicom čije su granice bile: da siroco S. Maria, da bora colina saso uiuo doue altre uolte era la uila Segareuac, da garbin il sopra detto tereno che e in mano delli Panizzoni, da maestro boschiuo, et pascolo. Zanimljiv je ovdje spomen selišta (villa) Šegarevac. Vjerojatno je riječ o selištu koje se nalazilo na potezu SI-I od Donjih Petrčana, na položaju koji se danas naziva Šaragovci. Usp. HR-DAZD-31, Simon Budineus (1556. - 1599.), b. I, fasc. VI, fol. 448r; HR-DAZD-338, Samostan sv. Dominika, kut. 3, br. 61c.

${ }^{106}$ HR-AZDN-43, Zadar - Sv. Stošija, Matrimonium II (1593. - 1604.), fol. 17r.

${ }^{107}$ Usp. HR-DAZD-31, Simon Mazzarellus (1555. - 1589.), b. I, fasc. III, fol. 24r-25r; HR-DAZD-31, Simon Mazzarellus (1555. - 1589.), b. I, fasc. VI, neozn. folija.

${ }^{108}$ HR-DAZD-31, Simon Mazzarellus (1555. - 1589.), b. I, fasc. XII, neozn. folija.

${ }^{109}$ Prezime Diklić zabilježeno je polovinom 15. stoljeća u Gorici pored Zadra. 1454. 18 aprile. Sentenza a favore di Simeone di Nosdrogna ed a danno di Giovanni e Paolo Diclich da Gorizza in punto rilascio del terreno posto in villa di Radovosello da lor tenuto a colonia. Š. LJUBIĆ, »Dva popisa listina«, str. 148. U vrijeme ninskoga biskupa Jakova Divnića (1523. - 1554.) spomenut je Vid Diklić iz Miljašića (Vito Dichlich della Villa Migliassich Diocese di Nona). HR-ASSMZD, Inventario, fol. 13r-v. O lokalnim migracijama u kasnijem razdoblju svjedoči podatak da su Diklići iz Gornjih Petrčana početkom 19. stoljeća doselili u Nin, a odatle dalje u Vrsi (zahvaljujem Ivni Anzulović koja me uputila na podatak, a koji joj je usmeno obznanio prof. dr. sc. Marjan Diklić). Usp. Šime BATOVIĆ, »Prezimena u Vrsima«, Vrsi kroz povijest. Zbornika radova I, Marjan DIKLIĆ (ur.), Vrsi, 2013., str. 322.

${ }^{110}$ Ivna ANZULOVIĆ, »Crkva sv. Marije od Duba ili Stublja, njezin položaj i srednjovjekovna sela na području nekadašnjeg Obrovca jugoistočno od Zadra«, Diadora, sv. 22, Zadar, 2007., str. 307.

${ }^{111}$ Usp. Bojan GOJA, »Zadarska stambena kuća u arhivskim izvorima 17. i 18. stoljeća«, Radovi Instituta za povijest umjetnosti, br. 41, Zagreb, 2017., str. 157-169; S. SORIĆ, »Utvrđeni ljetnikovac obitelji de Soppe na Bapcu«, str. 51.
} 
tvoreno dvorište. ${ }^{112}$ Ukupna površina nastambi bila je 236 pertika, što preračunato u m2 iznosi oko $578 \mathrm{~m} 2$. Uporabom alata za mjerenje površine na portalu Državne geodetske uprave (https://geoportal.dgu.hr) na označeni sklop kuća u Gornjim Petrčanima, k.o. Petrčane, k.č. 283, 284, 285, 286 i 287, dobiva se ekvivalentna površina, što upućuje na to da je riječ o nastambama petrčanskih kolona iz 16. stoljeća, oko kojih se formiralo današnje naselje (Slika 2). ${ }^{113}$

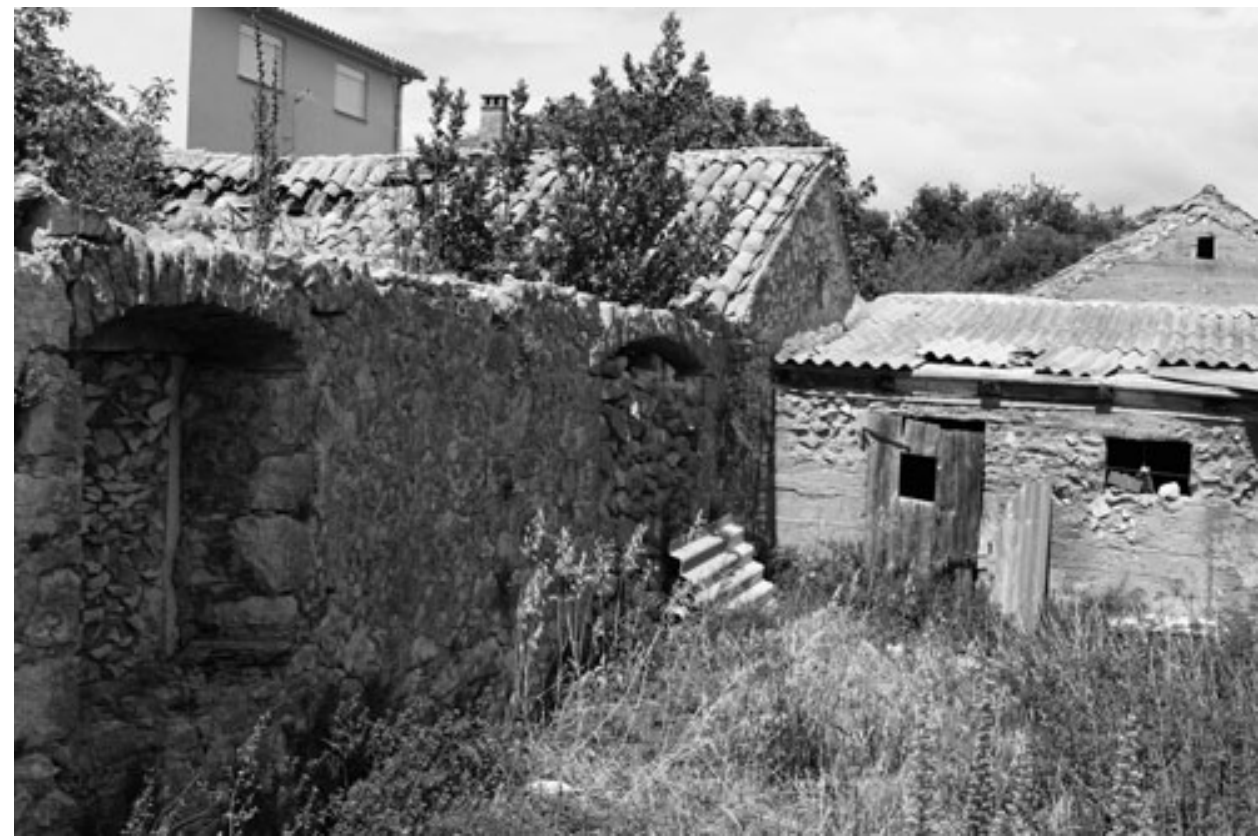

Slika 2. Detalj unutrašnjosti zatvorenoga dvorišta u sklopu kuća u Gornjim Petrčanima Foto: Z. Dundović

\footnotetext{
${ }^{112} \mathrm{O}$ tome vidi više kod: Zdravko ŽIVKOVIĆ, Tradicijska kamena kuća dalmatinskog zaleđa. Priručnik za obnovu i turističku valorizaciju, Zagreb, 2015.

${ }^{113}$ K.č. 286 k.o. Petrčane do danas je u posjedu obitelji Diklić, a površina staroga dijela u sklopu kuća iznosi oko $132 \mathrm{~m}^{2}$, što je ekvivalentno veličini od 54 pertike, koliko je naznačeno za nastambu Mate Diklića u 16. stoljeću.
} 


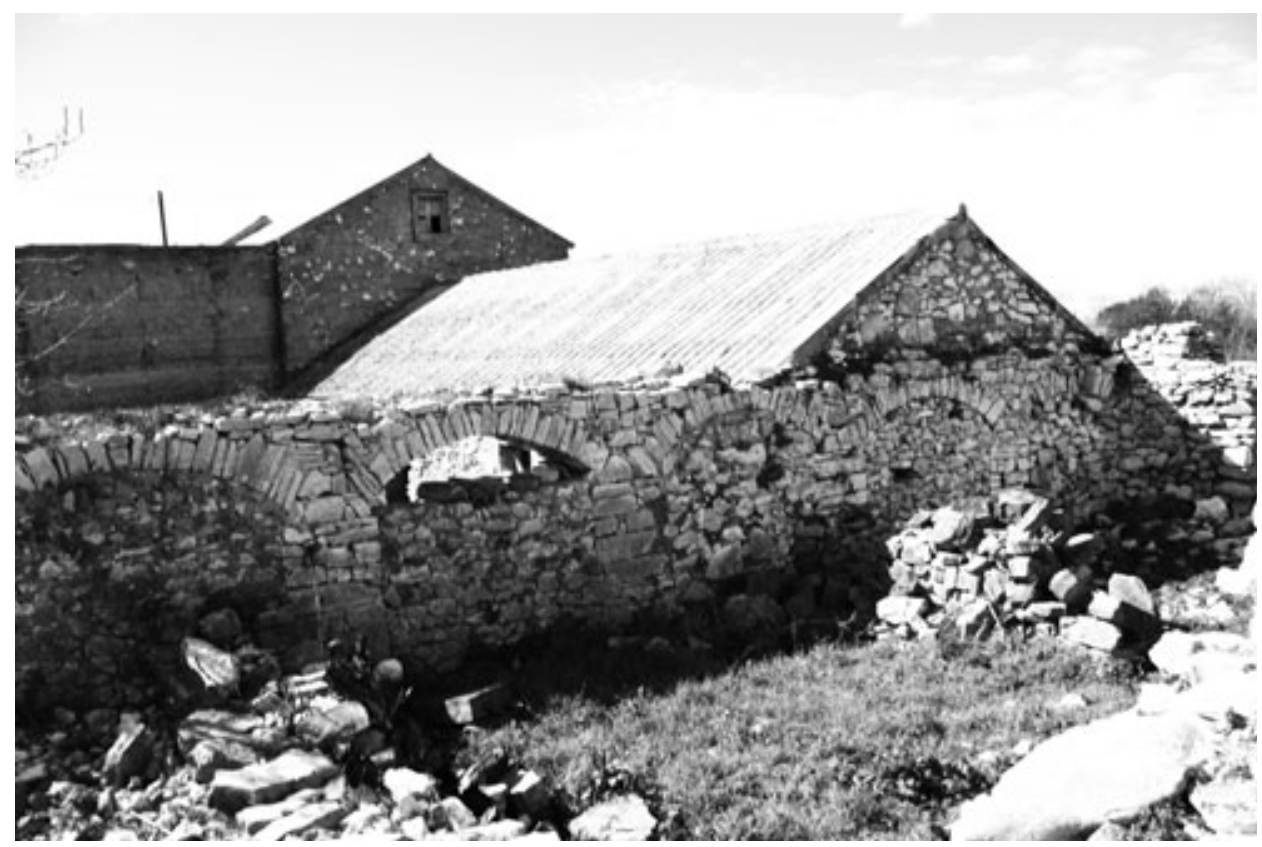

Slika 3. Detalj objekta u Ninskim Stanovima

Foto: M. Dubolnić Glavan

S obzirom na to da je na području susjednih Ninskih Stanova, na kojemu se nekada prostiralo selo Novoselci, uočena slična arhitektura nastambi, s lučnim otvorima u zatvorenom dvorištu, očito je riječ o identičnom pristupu pri formiranju selišta, odnosno nastambi kolona (Slika 3). ${ }^{114}$ Sačuvani izvorni ostatci arhitektonskoga sklopa samostanske ville, kule i utvrde na području Gornjih Petrčana iskusnom stručnjaku vjerojatno bi omogućili vjeran prikaz izgleda nekadašnjega naselja iz 16. stoljeća.

Opisi smještaja zemljišnih čestica koje su obrađivali petrčanski koloni izraženi su tadašnjim nazivima za strane svijeta: tramontana $(\mathrm{S})$, borra $(\mathrm{SI})$, ostro $(\mathrm{J})$, siroco $(\mathrm{JI})$, leuante (I), gherbin (JZ) i prouenza (SZ). ${ }^{115}$ Zemljišta su skupno bila podijeljena na ona u Grusinama i Polju. Usporedbom upisa o položajima zemljišnih čestica iz 16. stoljeća s modernim toponima na području S, SI i JI od današnjih Gornjih Petrčana, sa sigurnošću se može utvrditi da se taj cjelokupan prostor, koji je omeđivao samostansko selo, nazivao Grusina, a prostirao se S - SI preko današnjega cestovnog pravca Zadar - Nin, sve do položaja koji se i danas naziva Viševica, a zaveden je kao dio samostanskoga posjeda u ispravama

\footnotetext{
${ }^{114}$ Zahvaljujem kolegici dr. sc. Martini Dubolnić Glavan na ustupljenoj fotografiji.

${ }^{115} \mathrm{U}$ radu se pri opisu smještaja zemljišnih čestica dalje koristi kraticama hrvatskih oznaka za strane svijeta. O nazivima vjetrova i stranama svijeta vidi više kod: Vladimir SKRAČIĆ, »Nazivi vjetrova i strana svijeta u jadranskoj toponimiji «, Folia onomastica Croatica, br. 12/13, Zagreb, 2003., str. 433-448.
} 
(Visseuizza) ${ }^{116}$ na kojem su početkom 17. stoljeća Ivan Milutinović i Vuko Grubić iz Petrčana uzgajali proso (miglio) ${ }^{117}$ te u smjeru JI prema Kožinu sve do današnjih položaja Gaj i Podgajnice. U prilog tome zaključku idu morfološke značajke tla na tom području te etimologija toponima Grusine (gruh: sitno kršje). ${ }^{118}$

Polje označava plodne zemlje koje su se prostirale unutar granica današnjih Petrčana, Gornjih Petrčana, Kožina i Bartulca, za koje je u 17. stoljeću naznačeno da su rađale pšenicom iznimne kakvoće i maslinama od kojih se dobivalo dobro ulje. ${ }^{119}$ Osim povoljnoga fertiliteta tla, na tom području zabilježeno je izobilje vodnih resursa. ${ }^{120} \mathrm{Za}$ sva zemljišta koja su obrađivali petrčanski koloni naznačene su površine u gonjajima, kvartama i pertikama. ${ }^{121}$ No, usporedbom upisa tih površina u inventaru posjeda samostana sv. Katarine i $\mathrm{u}$ administrativnim knjigama razvidno je da je pisar često griješio kod pretvaranja pertika u gonjaje i kvarte, što je u konačnici ispravljeno kod ukupnoga zbroja površina čestica koje su pojedini koloni obrađivali te se u radu navode isključivo te sumarne vrijednosti.

Ivan Paić obrađivao je sveukupno 29 gonjaja, tri kvarte i šest pertika zemljišta. Njegova nastamba (la casa ouer stancia) bila je veličine 48 pertika. Za nju je naznačeno da se nalazila unutar obrambenoga zida (dentro del reuelino). ${ }^{122}$ Ostatci revelina s puškarnicama vidljivi su u Gornjim Petrčanima i danas, iako se oko njih formiralo novo naselje, a vjerojatno je obrambeni zid tijekom stoljeća doživio i druge pregradnje (Slika 4). ${ }^{123}$

\footnotetext{
${ }^{116}$ U Petrčanima postoji uvala i položaj iznad nje koji se naziva Viševica, a smješten je SZ od Gornjih Petrčana, no s obzirom na podatke o položajnom smještaju zemljišta iz samostanskih isprava isključena je mogućnost da bi bila riječ o tom položaju. Da je riječ o položaju smještenom SI od današnjega prometnoga pravca Zadar - Nin potvrđuje i činjenica da je za k.č. 15 k.o. Petrčane, pod imenom Viševica, naznačeno da se vodi spor postupka naknade za oduzetu imovinu samostana benediktinki sv. Marije u Zadru, koje su u posjed toga zemljišta došle nakon prelaska koludrica sv. Katarine u samostan sv. Marije 1804. godine i spajanja dvaju samostanskih zajednica u jednu. Usp. C. F. BIANCHI, Zara Cristiana I, str. 444.

${ }^{117}$ HR-ASSMZD, Inventario, fol. 52.

${ }^{118}$ Usp. Vladimir SKRAČIĆ, Ante JURIĆ, »Krški leksik zadarske regije«, Geoadria, god. 9, br. 2, Zadar, 2004., str. 164-165.

${ }^{119}$ Tea MAYHEW, Dalmatia between Ottoman and Venetian Rule. Contado di Zara 1645 - 1718, Roma, 2018. str. 113.

${ }^{120}$ Usp. Mate KLARIĆ, »Obrovac sredovječnih isprava (od X. do XIV. vijeka)«, Vjesnik arheološkog muzeja u Zagrebu, god. 16, br. 1, Zagreb, 1935., str. 45.

${ }^{121}$ Od 16. stoljeća zadarski gonjaj ili gonjal iznosio je točno $2.363 \mathrm{~m}^{2}$. Marija ZANINOVIĆ-RUMORA, »Stare mjere za površinu u sjevernoj Dalmaciji«, Radovi Zavoda za povijesne znanosti HAZU u Zadru, br. 35, Zadar, 1993., str. 127.

${ }^{122}$ Rezultati dosadašnjih istraživanja pokazuju da se najčešće uz vlasnikovu kuću ili u sklopu nje nalazio stan obitelji seljaka dvornika (gastald), iz čega se može zaključiti da je Ivan Paić bio dvornik samostanskoga posjeda (villa) sv. Katarine. Usp. S. SORIĆ, »Utvrđeni ljetnikovac obitelji de Soppe na Bapcu«, str. 48, bilj. 6; T. RAUKAR, Zadar u XV. stoljeću, str. 167.

${ }^{123}$ Zanimljiv detalj u zidovima zgrada za koje se pretpostavlja da su pripadale samostanskoj kuriji (gospodarske zgrade) su ugrađeni listovi starih motika između kamena, vjerojatno iz 19. st., čije ušice vire, a prema kazivanju lokalnoga stanovništva služile se za privezivanje tovarnih životinja. S obzirom na to da su zamijećene na nekoliko starijih zgrada unutar obrambenoga zida, ali i u susjednom naselju Zaton, ne treba isključiti i njihovu moguću simboličnu ili mitološku ulogu, kao relikt starih vjerovanja. Primjerice, u literaturi je zabilježeno da bi se kod starih Etruščana plugovi, motike i ostali alat koji se koristio pri izgradnji gradova zazidali za dobru sreću u jednu prostoriju ili zidanu cisternu, koja se nazivala Roma quadrata. Giuseppe Antonio GUATTANI, Lezioni di storia, mitologia e costumi, Roma, 1839., str. 16. O uporabi alatki kao zaštite od groma ili možda osobne zaštite vlasnika kao običaju koji je prenijet iz poganskih i prapovijesnih vremena (praslavenskih i praindoeuropskih) i zadržao se do naših dana kao dio tradicijske kulture vidi rad: Tonči BURIĆ, »"Strilni kamen“" s Baba Lokve«, Archaeologia Adriatica, god. 9, br. 1, Zadar, 2015., 351-364.
} 


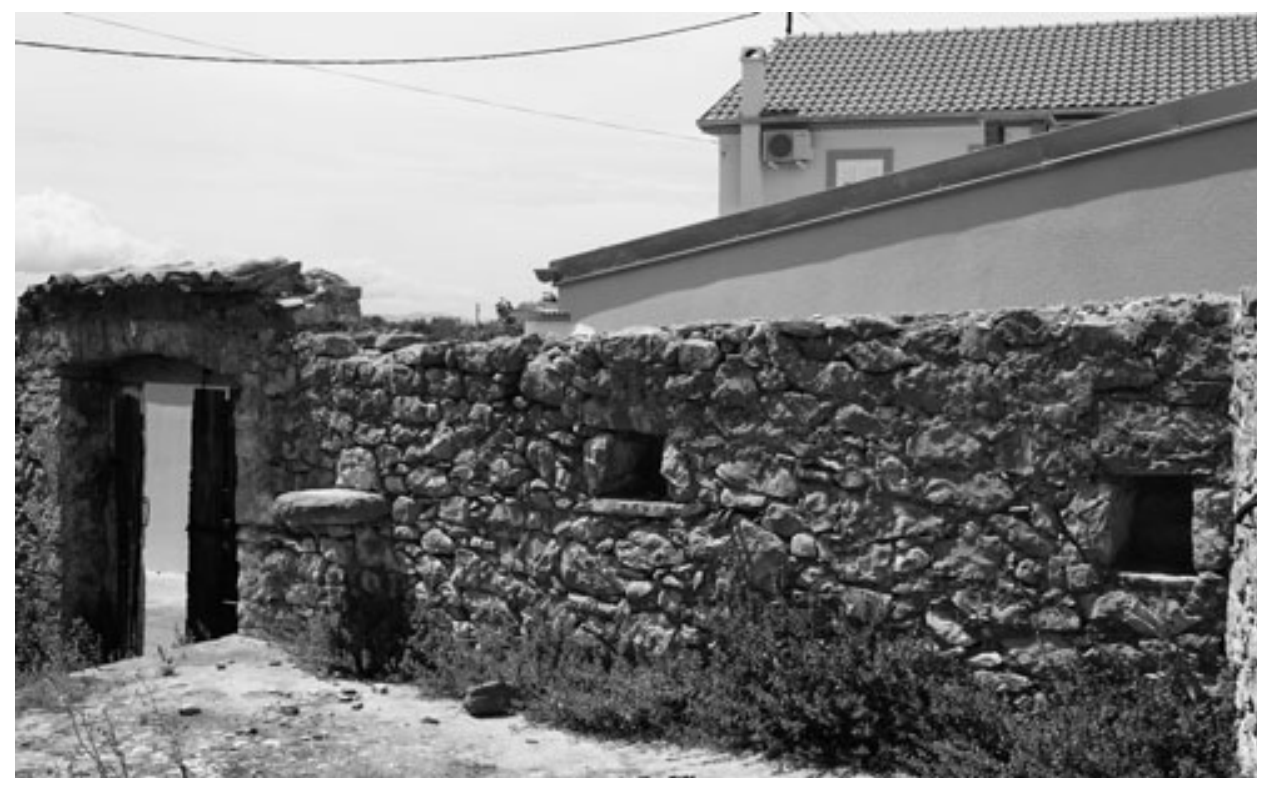

Slika 4. Ostatci revelina s puškarnicama u Gornjim Petrčanima danas Foto: Z. Dundović.

Ispod vrta Ivana Paića bila je smještena podvornica ${ }^{124}$ (la poduorniza sotto il suo orto). ${ }^{125}$ U registru samostana sv. Katarine naznačena je njena duljina: longheza da siroco e prouenza perteghe 129. ${ }^{126}$ Paić je obrađivao vrtove koji su bili smješteni JZ od sela iznad puta (horti da gherbin della uilla oltra la strada). ${ }^{127}$ Težaci su imali pravo koristiti se dijelom zemljišta za vlastiti vrt, za što su nerijetko zemljoposjednicima bili dužni davati darove (honoranze). ${ }^{128} \mathrm{U}$ inventaru je naznačeno da su petrčanski koloni za korištenje kuće i vrta davali godišnje jedan četvrtalj pšenice, jednu kokoš ili lonzu (pečenica) al patrone della Villa, odnosno samostanu sv. Katarine. ${ }^{129}$

Paić je obrađivao komad zemljišta SI od zgona (da borra del sgono) te jednu špeticu SZ od podvornica (vna spetiza da prouenza delle poduornizze), ${ }^{130}$ a ispod zgona na položaju

${ }^{124} \mathrm{U}$ kasnome srednjem vijeku podvornica je označavala dio ždrijeba na kojemu je kmet bio nastanjen i obrađivao zemljište isključivo za sebe, odnosno od njega nije davao rentu. T. RAUKAR, Zadar u XV. stoljeću, str. $166-167$.

${ }^{125}$ HR-ASSMZD, Inventario, fol. 1r.

${ }^{126}$ HR-ASSMZD, Libro delle monache de Santa Catarina, sv. 2, fol. 261r.

${ }^{127}$ HR-ASSMZD, Inventario, fol. 1r.

${ }^{128}$ Usp. L. ČORALIĆ, »Zemljišni posjedi«, str. 221.

${ }^{129}$ Čini se da je to bila uobičajena honoranza jer su identičnu davali koloni na posjedu Bruscandolijevih: un quartarolo grande di formento, et una galina o uer la lonza al padrone della uila e questo per recognizione della casa, et orto. Moguće je da je to bila honoracija „prema starom običaju“. HR-DAZD-338, Samostan sv. Dominika, kut. 3, br. 61c. Usp. T. RAUKAR i dr., Zadar pod mletačkom upravom, str. 252.

${ }^{130}$ Uporaba množine poduornizze i njihov smještaj potvrđuju da je samostansko selo u Gornjim Petrčanima slijedilo uobičajenu strukturu raspodjele kasnosrednjovjekovnih posjeda na kojima su sve podvornice bile okupljene na jednome mjestu. Usp. T. RAUKAR, Zadar u XV. stoljeću, str. 170-171. 
Grbe zemljište SZ od Devenešićeva (sotto Gherbe da prouenza del Venesich). ${ }^{131}$ Položaj Grbe poznat je i danas, a smješten je JZ od položaja Zgon. Zemljišta položena SZ i JZ od sela nazivaju se Podvornice (Podvornica), a Z od njih preko ceste koja vodi u Donje Petrčane prostire se obradiva čestica koja se i danas zove Zgon, od kojega su SZ položene Špetice, što potvrđuje da su se stari toponimi sačuvali do danas. Izgledno je da je pojam špetica označavao zemljišne čestice manje površine, što je naznačeno u pojedinim skicama (Slika 5). ${ }^{132}$ Špetica očito nije imala određenu vrijednost jer se u istraženim izvornicima njezina površina proteže od jedne kvarte do tri kvarte i 90 pertika, odnosno nikada preko jednoga gonjaja. ${ }^{133} \mathrm{U}$ blizini obrambenoga zida, na vrhu podvornica u Gornjim Petrčanima nalazi se do danas kamenom obzidana lokva, koju su održavali koloni.

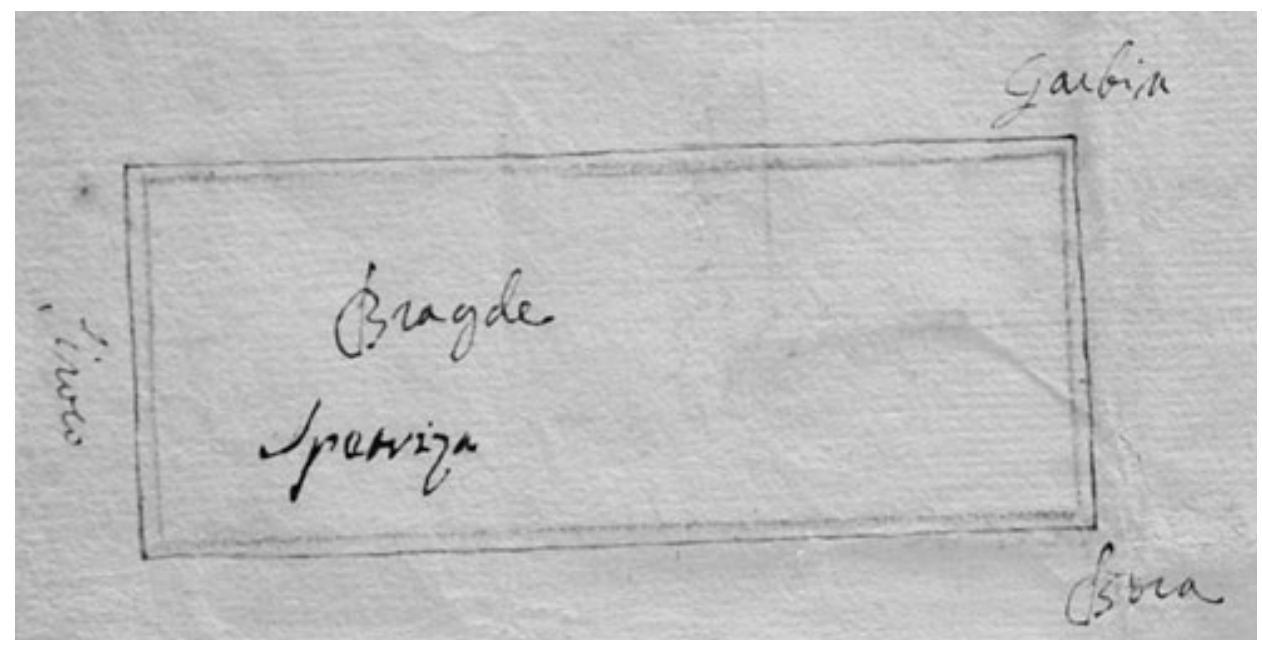

Slika 5. Skica zemljišne čestice obitelji Hmeljković, na kojoj je naznačen pojam špetica Izvor: HR-DAZD-338, Samostan sv. Dominika, kut. 3, br. 61c

Za Paićevu oranicu na položaju Brnestrice (Bernestricie), koja je graničila sa samostanskim posjedima u Kožinu, naznačene su sljedeće granice: »da sirocco le raggione del Reuerendo Archidiacono, da Gherbin Meser Simon Gliubauaz, da Borra monte de Cozinoselo,

\footnotetext{
${ }^{131}$ HR-ASSMZD, Inventario, fol. 1r.

${ }^{132}$ Između Dikla i Kožina do danas postoji put koji se naziva Put špetica. Pojam špetica povezan je s veličinom obradivoga zemljišta, a na Pašmanu se rabio za označavanje gromade živoga kamena kojim je ispresijecano obradivo zemljište. U bibinjskome rječniku pod pojmom špetica podrazumijeva se mala parcela, parcelica. U radu Ante Šupuka također je navedeno da je riječ o maloj zemljišnoj čestici, a prema njemu pojam špetica vuče podrijetlo od tal. pezzetta (komadić). Usp. Dunja BROZOVIĆ RONČEVIĆ - Ankica ČILAS̆ S̆IMPRAGA - Domagoj VIDOVIĆ, »Suvremena toponimija otoka Paga«, Toponimija otoka Paga, Vladimir SKRAČIĆ (ur.), Zadar, 2011., str. 659; Božidar ŠIMUNIĆ, Rječnik bibinjskoga govora. Rječnici/8, Zadar, 2013., str. 691; Ante ŠUPUK, Šibenski glagoljski spomenici od 1547. do 1774., Zagreb, 1957., str.

${ }^{133}$ Jedan gonjaj iznosio je četiri kvarte.
} 
da prouenza li Bruscandoli « ${ }^{134}$. C. F. Bianchi je na dvama mjestima naveo da je obitelj Bruscandolo (Hmeljković) bila u vlasništvu zemljišta na području naselja Bartulac ili Sv. Bartula, što potvrđuju i izvori, ${ }^{135}$ a oporučno ih je ostavio samostanima sv. Dominika, sv. Katarine i sv. Marcele Ivan Vinko Bruscandolo 19. lipnja 1579. godine. ${ }^{136} \mathrm{O}$ tome svjedoči spor koji se oko tih posjeda vodio tijekom 17. stoljeća, a cjelovit popis Hmeljkovićevih (Bruscandolijevih) zemljišnih čestica, zajedno sa skicama i naznakama međaša pohranjen je u fondu samostana sv. Dominika u Državnom arhivu u Zadru, što pomaže lakšem pozicioniranju zemljišnih čestica samostana sv. Katarine na prostoru polja koje se do danas proteže unutar granica Petrčana, Gornjih Petrčana, položaja Kuline (Sv. Bartula) i Kožina (Slika 6). ${ }^{137}$

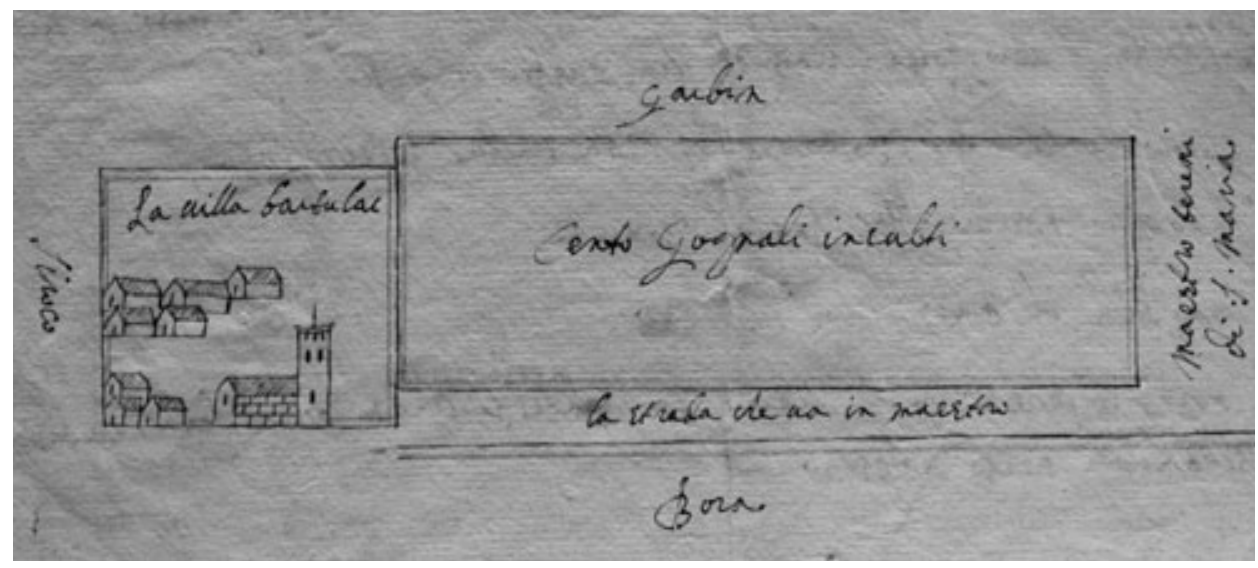

Slika 6. Skica selišta Bartulac i oznake međaša iz prve polovine 17. stoljeća. JZ (garbin) je more Izvor: HR-DAZD-338, Samostan sv. Dominika, kut. 3, br. 61c

To se napominje stoga što je obitelj Bruscandolo (Hmeljković) imala posjede u Novoselcima blizu Nina, a dijelom su graničili s posjedima samostana sv. Marije u Zadru. ${ }^{138}$ Tri

\footnotetext{
${ }^{134}$ Položaj Brnestrice i danas se tako naziva među stanovništvom Kožina. Riječ je o položaju koji se prostire uz makadamski put kojim se iz Kožina sa SI dolazi do zapuštenoga zdenca u Gornjim Petrčanima. Ime je dobio po brnistri (žuka, lat. Spartium junceum) koja i danas cvjeta na tom području, a SI od toga položaja smješteno je na uzvisini selo Kožino (Monte de Cozinoselo).

${ }^{135}$ Riječ je o posjedima obitelji Hmeljković, koji podrijetlo vuku iz Knina, a prezime im se u izvornicima javlja u oblicima: Hmilcouich, Hmeglcouich, Hmiglcouich, Milchouich. Nazivali su se još i Bruscandol. Posjedovali su zemljišta u Petrčanima i Novoselcima. Ugovor o kupovini posjeda u Novoselcima zabilježen je u spisima bilježnika Šimuna Mazzarella. Posjed su kupila braća svećenik Grgur i Vinko Hmeljković, sinovi Ivana iz Knina, po zanimanju krznara. Usp. Ivna ANZULOVIĆ, »Ninska plemićka obitelj Pritičević i njihova kuća u Novigradu«, Starohrvatska prosvjeta, vol. 3, br. 36, Split, 2009., str. 408-409; HR-DAZD-31, Simon Mazzarellus (1555. - 1589.), b. I, fasc. II, neozn. folija.

${ }^{136}$ Bianchi je pogrešno naveo datum oporuke. Riječ je o oporuci od 17. lipnja 1579. godine, koja je pohranjena u spisima javnoga bilježnika Šimuna Turina. Usp. Carlo Federico BIANCHI, Kršćanski Zadar, sv. 2 (prev. Velimir ŽIGO), Zadar, 2011., str. 356, 398.

${ }^{137}$ HR-DAZD-338, Samostan sv. Dominika, kut. 3, br. 61c.

${ }^{138}$ Usp. HR-DAZD-338, Samostan sv. Dominika, kut. 5, br. 160.
} 
ždrijeba zemljišta u vlasništvu samostana sv. Marije nalazila su se u Novoselcima, bila su iznajmljena 1562. i 1563. godine za 20 lira Ivanovu bratu, svećeniku i zadarskom kanoniku Grguru Hmeljkoviću (p. Gregorio Meglcouich), a naznačeno je da ih seljani nisu obrađivali (non senta nisun villan). ${ }^{139} \mathrm{Na}$ njima su kasnije obrađivali zemlje koloni benediktinskih samostana sv. Marije i sv. Katarine iz Petrčana, Glupavca (Gornje Petrčane) i Bartulca, što je naznačeno na priloženoj topografskoj skici nepoznatoga autora, moguće iz 17. ili početka 18. stoljeća (Slika 7). ${ }^{140}$ Vjerojatno je samostan sv. Katarine ušao u posjed zemljišta u Novoselcima tijekom 17. stoljeća jer je u katastru posjeda hospitala Sv. Duha ili gubavaca (de leprosi) iz 1683. godine, koji su graničili s posjedima Hmeljkovića u 16. stoljeću, naznačen kao međaš. ${ }^{141}$

Sljedeće Paićevo zemljište bilo je položeno JI od drage Bruscandola, a u blizini još jedno koje je graničilo da Gherbin de Bruscandoli, da Borra del pozo Verbiza. ${ }^{142}$ Položaj i zdenac Vrbica i danas postoje, ${ }^{143}$ a opravdana je pretpostavka da se dragom Bruscandola nazivao položaj koji je danas zabilježen kao Drage, JZ od položaja Civaleština, a proteže se do granica Sv. Bartula. ${ }^{144}$ Obilaskom terena zamijećena je nekad održavana, kamenom obzidana, a danas zapuštena draga, koja se spuštala prema moru nedaleko od utvrde Kulina, čiji se smještaj poklapa s opisima graničnih zemljišta samostana sv. Katarine između Petrčana i Kožina, a označena je i na spomenutoj topografskoj skici.

\footnotetext{
${ }^{139}$ IT-ASVe, Sopraintendenti alle decime del clero, pezzo 39, br. 5, fol. 5 r.

${ }^{140}$ Zahvaljujem Josipu Faričiću na ustupljenoj topografskoj skici, koja je dio njegova rada Ninska biskupija na ranonovovjekovnim kartama za budući Zbornik o prošlosti Ninske biskupije. Isječak te skice objavio je Ivo Petricioli. Ivo PETRICIOLI, »Tri romaničke crkve u Diklu«, Starohrvatska prosvjeta, vol. 3, br. 4, Split, 1955., str. 177, sl. 1.

${ }^{141}$ Znanstvena knjižnica u Zadru (dalje: ZKZD), sign. 10645, ms. 73, fol. 72.

${ }^{142}$ Vjerojatno je riječ o zemljištu uz posjed Bruscandolijevih na Vrbici, za koje su navedeni sljedeći međaši: da bora colina saso uiuo, et pascoli, da siroco in parte $S$. Catarina, et in parte Bruschandoli, da maestro $S$. Catarina, da garbin S. Catarina. HR-DAZD-338, Samostan sv. Dominika, kut. 3, br. 61c.

${ }^{143}$ Hidronim Vrbice dolazi od umanjenice za vrbe, a označava položaj uz koji je voda, u ovom slučaju zdenac. Osim samostana sv. Katarine, na položaju Vrbica (ispod zdenca) u posjedu zemljišnih čestica bio je i samostan sv. Marije, što je razvidno iz ugovora o koncesionalnom najmu od 29. listopada 1555. godine kojim se postolaru Jurju Jurčiću pok. Andrije iz Ljupča, stanovniku Zadra, daje ad pastinandum et plantandum komad zemljišta veličine oko četiri gonjaja positum in pertinentis uille Peterzani in loco uocato Verba. HRDAZD-31, Simon Mazzarellus (1555. - 1589.), b. I, fasc. I, neozn. folija.

${ }^{144}$ Stari toponimi sačuvani su do danas i gotovo do u detalje dopuštaju mogućnost lociranja pojedinih posjeda. Primjerice, 5. listopada 1557. godine svećenik Juraj Hmeljković i brat mu Vinko dali su ad plantandum ac pastinandum Franji, sinu Mate Lošinjanina, stanovniku in uilla Peterzane districtus Jadre, oko dva gonjaja oranice in pertinentis dicti loci Peterzane a parte sirocali juxta ecclesiam Sancti Bartholomei infra hos confines. A syroco ut dixerunt, a borea et quirina iura illorum de Jordanis, et a trauersa iura nobilium fratrum domini Gregorii, et Donati Ciuallelli seu heredes quondam sp. domini Zoyli de Pechiaro saluis et ceteram. U k. o. Petrčane k. č. 2287/1 do danas nosi ime Civaleština, a isto ime nose i čestice koje se nastavljaju JI od te u k. o. Diklo. SZ i JZ od položaja Civaleštine smještene su danas Brajde Ardanića (Jordanića). Čini se da je u ovom slučaju riječ o položaju Biline, na kojem su Bruscandoli posjedovali ukupno pet gonjaja zemljišta, što je zapisano u posjedovniku iz fonda samostana sv. Dominika. Primjenom alata za mjerenje površine na današnje položaju Biline, koji je upisan u k. o. Petrčane pod k. č. 2268, 2269 i 2270., dobiva se ekvivalentna površina u $\mathrm{m}^{2}$. SI od toga položaja prostire se danas Civaleština. Usp. HR-DAZD-31, Simon Budineus (1556. - 1599.), b. I, fasc. II, fol. 76r; HR-DAZD-338, Samostan sv. Dominika, kut. 3, br. 61c.
} 


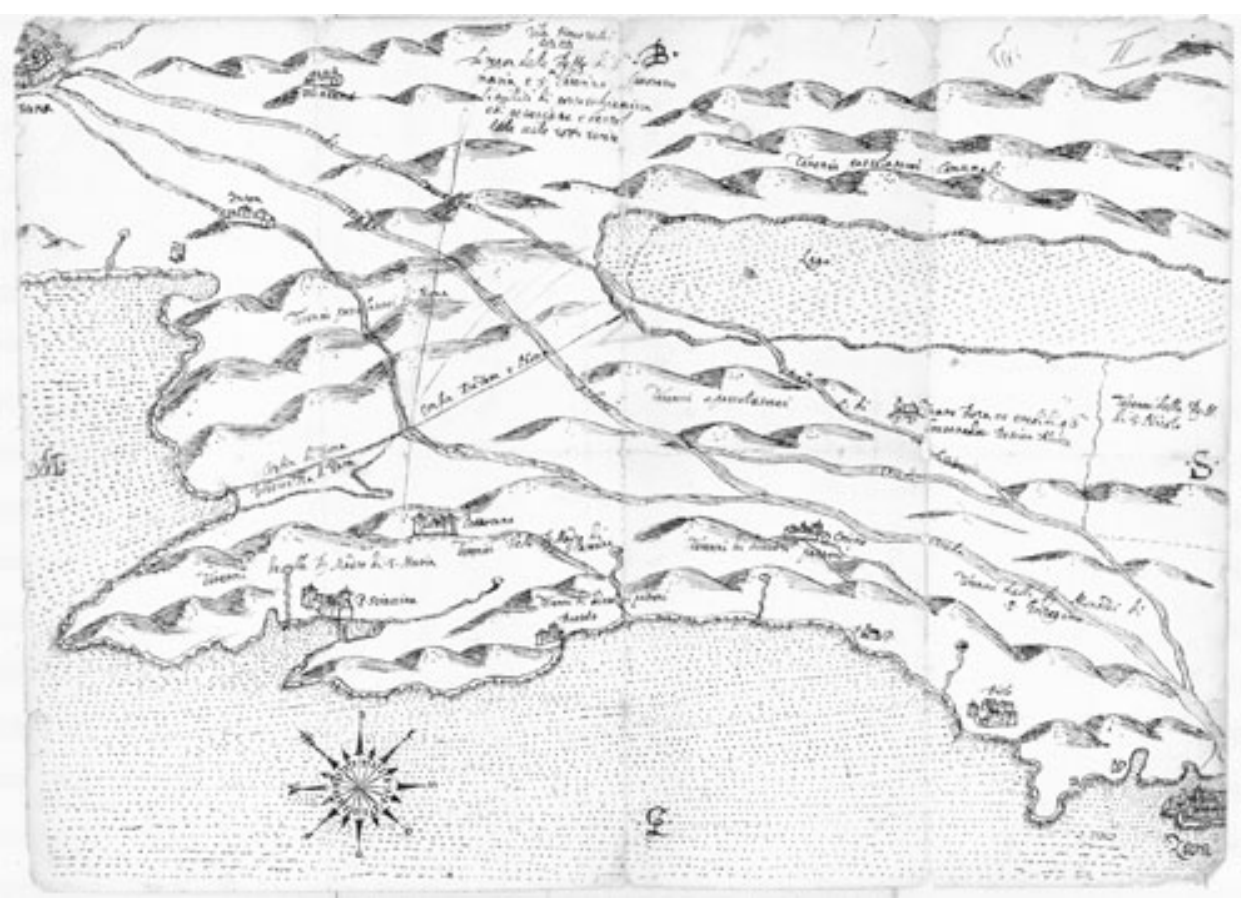

Slika 7. Topografska skica prostora između Nina i Zadra, Zadar, nepoznati autor (17. ili 18. st.) Izvor: HR-DAZD-6, Mape Grimani, Sign. 266

Sljedeći Paićev teren prostirao se S od Vrbice, a SI prema zemljištu Petra Venešića. SI od puta koji vodi za Nin, na položaju Grussina, obrađivao je dva zemljišta, od kojih je jedno bilo položeno JI od drugoga. Posljednji teren, odnosno oranica s pretežito kamenitim tlom (arado saxoso) prostirala se JI od puta za selo. ${ }^{145}$

Nastamba Ivana Milutinovića bila je veličine 56 pertika. Posjedovao je vrtove na položaju Grusine i SI od sela. Ispod njegova vrta prostirala se podvornica. SI od novoga zgona (del sgono nouo) obrađivao je zemljišta, a SZ od podvornica jednu špeticu. Milutinović je obrađivao komad zemljišta JZ od zemljišta Mate Diklića južno od granica Kožina. Jednako SZ od Diklićevih zemljišta prostiralo se Milutinovićevo zemljište na položaju Pod Grabar. ${ }^{146} \mathrm{JZ}$ od Ivana Paića, a JI od drage Bruscandola, na položaju zva-

\footnotetext{
${ }^{145}$ HR-ASSMZD, Inventario, fol. 1v.

${ }^{146}$ Toponim Pod Grabar nastao je od vrste stabla, bijeloga graba, koji zajedno s hrastom meduncom tvori najznačajniju klimatskozonsku šumsku zajednicu submediteranske zone priobalnog pojasa sjevernoga Hrvatskog primorja, od Istre do Dubrovnika. S obzirom na to da je u ispravama spomenuto brdo Grabar (Monte Grabar), čini se da bi taj položaj danas trebalo tražiti na potezu između današnjih položaj Podgajnice i Brdina prema Kožinu. Obilaskom terena s dipl. ing. šumarstva Denisom Miočićem na tom položaju zamijećena su stabla hrasta medunca i jasena, no bijeli grab je iz zasad nepoznatoga razloga iskorijenjen. Usp. Đuro RAUŠ - Ivo TRINAJSTIĆ - Joso VUKELIĆ - Juraj MEDVEDOVIĆ, »Biljni svijet hrvatskih šuma«, Šume u Hrvatskoj, Đuro RAUŠ (ur.), Zagreb, 1992., str. 40-41.
} 
nom Ograda, ${ }^{147}$ obrađivao je manju zemljišnu česticu. ${ }^{148}$ Tri sljedeća zemljišta prostirala su se kako slijedi: prvo iznad Vrbice, drugo S od Vrbice, koje se nastavljalo na treće, koje se prostiralo SI od zemljišta Petra Venešića. Na Grusini je Milutinović obrađivao tri komada zemljišta. Jedno je bilo položeno iznad vode (sopra l'agua) JI od sela. Čini se da je to zemljište bilo položeno iznad današnjega položaja Podlokve ili Lokva, od kojega prema SI vodi put prema Kožinu i položaju Brnestrice, na kojem danas stoji maslinik naziva Čačinovka, vjerojatno po kolonu Čačinoviću. ${ }^{149}$ SI od toga zemljišta u Grusinama bilo je položeno drugo, a graničilo je sa zemljištem kolona Čačinovića. Treće zemljište bilo je položeno po sredini (in mezo) Grusina. Sveukupno je Milutinović na posjedu samostana sv. Katarine u Petrčanima obrađivao 19 gonjaja, 3 kvarte i 53 pertika zemljišta. ${ }^{150}$

Nastamba Mate Diklića bila je duljine devet koraka ili paša (passo), ${ }^{151}$ a širine šest paša, što je iznosilo 54 pertike, dok su vrtovi u njegovu posjedu iznosili tri kvarte i 22 pertike. Ispod vrta bila je položena podvornica. Diklić je obrađivao zemljište SI od staroga zgona (sgono uechio), uz lokvu. Usto je posjedovao špeticu uz podvornicu ispod sela. Druga Diklićeva špetica bila je položena JI od podvornica, a JZ od staroga zgona. Diklić je uživao zemljište ispod granica Kožina. JI od drage Melkovica (uale di Melcouiza), na položaju Pod Grabar, obrađivao je zemljište sa sljedećima granicama: da siroco Meser Ludouico Nassi, ${ }^{152}$ da gherbin Meser Pompeo Soppe, da prouenza Bruscandoli, da borra Monte detto Grabar. Sljedeće Diklićevo zemljište bilo je položeno JI od drage Bruscandola, a JZ od zemljišta koja je obrađivao Ivan Milutinović. ${ }^{153}$ Diklić je obrađivao komad zemljišta JZ od Bruscandolijevih. Na zemljištu koje se prostiralo S od Vrbice, a SI od zemljišta koja je

\footnotetext{
${ }^{147}$ JI od Drage (draga Bruscandola), ispod Puta sv. Bartula i položaja Plat, položaj na kojem su danas sve do mora izgrađene mnoge obiteljske kuće i apartmanske jedinice, naziva se Ograde.

${ }^{148}$ HR-ASSMZD, Inventario, fol. $2 \mathrm{r}$.

${ }^{149} \mathrm{U}$ prilog tomu navodi se da je položaj Polipine bio u vlasništvu Bruscandola. Bila je riječ o 20 gonjaja zemljišta koje je graničilo: da garbin de Marchis, da maestro S. Maria, da bora S. Catarina, da siroco de Marchis in parte, et in parte Spingaroli. Položaj Polipine i danas postoji, a prostire se SZ od Vrbice, i JZ-Z od položaja Pod Lokve. Usp. HR-DAZD-338, Samostan sv. Dominika, kut. 3, br. 61c.

${ }^{150}$ HR-ASSMZD, Inventario, fol. 2v.

${ }^{151}$ Jedan korak ili paš (passo) iznosio je $1.73868 \mathrm{~m}$. Mirela SLUKAN-ALTIĆ, »Povijest mletačkog katastra Dalmacije «, Arhivski vjesnik, br. 43, Zagreb, 2000., str. 179, bilj. 26.

${ }^{152}$ Posjedi Nassijevih u Kožinu zabilježeni su početkom 16. stoljeća na položaju Polombaršćina (Polombarschina). O tome svjedoči zapis u spisima bilježnika Antonija de Zandonatisa: 1509. 27. gennaro, per maistro Piero Sidinich fabro, aquisto dal Zuanne Zoijzinouich da Cosinosello, di gognali $13 / 4$ di capi viti posti in detta villa Cosino in loco Polumbarschina sopra fondi Nassi, per L 26 de piccoli. Nassijevi su širili svoje posjede u Kožinu o čemu svjedoči kupoprodajni ugovor između zadarskih plemića i braće Ivana Battiste i Ludovika i nasljednika obitelji Civran iz Murana od 2. lipnja 1555. godine: Item pro una allia possessione tota et integra, quantacumque ad presens reperitur dictorum fratrum de Nassis posita in uilla Cosino Sello, cum omnibus suis iuribus actionibus habentiis, et pertinentis. Et quia neque cum possessio simiter confinari habiter non potest. Ideo totius dictae uille Cosinosello districtus Jadre hos affermarunt esse confines de siroco Villa Diclo de borea uilla Peterzane De trauersa mare et de quirina Blato, saluis etc. Međutim, bilježnik je u opisu granica sela Kožina pogrešno naveo da je more SI (de trauersa), a selo Blato JZ (de quirina) od Kožina, jer je prostorni smještaj obrnut. More je JZ (de quirina) od Kožina, a selo Blato bilo je SI (de trauersa). Slične pogreške u opisima granica već su zabilježene u literaturi. Usp. HR-DAZD-31, Simon Mazzarellus (1555. - 1589.), b. I, fasc. I, neozn. folija; Ivna ANZULOVIĆ, »Područje sela Korlata u prošlosti«, Zadarska smotra, br. 1-3, Zadar, 1996., str. 250, bilj. 48; str. 251, bilj. 55; S. GUNJAČA, »Repertorium actuum «, str. 319, 338.

${ }^{153}$ HR-ASSMZD, Inventario, fol. 3r.
} 
obrađivao Čačinović, prepoznaje se današnji položaj Draga Diklića. Na položaju Grusina, S od granice s posjedom benediktinskoga samostana sv. Marije bilo je položeno Diklićevo zemljište, a još jedno SZ od toga. U blizini sela od JI, na položaju Grusina, Diklić je obrađivao zemljište na sitnom kršju (saxoso). Sveukupno je Diklić obrađivao 18 gonjaja, tri kvarte i dvije pertike samostanskoga zemljišta. ${ }^{154}$

Nastambu veličine 72 pertike dijelili su težaci Ivan Čačinović i Mate Pavić. Čačinović je posjedovao vrt ispod nastambe. Drugi vrt bio je položen SZ od sela na položaju Grusine, premjeren u križ (pertigato in croxe). Čačinović je obrađivao dvije podvornice ispod vrta. SI od novoga zgona obrađivao je komad zemljišta, a JI od podvornica jednu špeticu. Čačinović je obrađivao komad zemljišta na granici s Kožinom, a bio je smješten JZ od zemljišta koja je obrađivao Petar Devenešić. Čačinović je preuzeo napušteno zemljište pod vinogradom SI od Jordanićeve šume (bosco di Jordanich). ${ }^{155} \mathrm{Na}$ tom potezu protežu se do danas Brajde Ardanića (Jordanića), a ime položaja (Brajde) implicira da je bila riječ o vinorodnim zemljištima. Moguće je da je riječ o vinogradu koji je početkom 17. stoljeća obrađivao Šimun Čačinović, vjerojatno Ivanov nasljednik, a koji je samostan sv. Katarine dobio oporukom Ivana Bruscandola (Hmeljkovića) iz 1579. godine, na položaju Draga iznad kaštela u Bartulcu, što se poklapa s opisom granica. ${ }^{156} \mathrm{Na}$ položaju Pod Grabar (sotto Grabar), SZ od zemljišta koje je obrađivao Milutinović, bilo je položeno jedno njegovo zemljište, a drugo u dragi Bruscandola prema JI (della ualle del Bruscandolo per sirocco). ${ }^{157}$ To su bili položaji na granici posjeda s Kožinom, a danas je na tom području granica između k.o. Petrčane i k.o. Diklo.

Čačinović je dva zemljišta obrađivao na položaju Vrbice, jedno SI od zdenca Vrbice (pozzo Verbiza), ${ }^{158}$ te drugo S od Vrbice, a SI od zemljišta Ivana Milutinovića. Čačinovićevo zemljište na Grusini I od puta za Nin (per leuante della uia di Nona) može se točnije locirati. Čini se da je riječ o položaju koji se danas naziva Čačinka, a položen

\footnotetext{
${ }^{154}$ Isto, fol. $3 \mathrm{v}$.

${ }^{155}$ Opravdana je pretpostavka da je riječ o šumi pretežito hrasta crnike koja se danas prostire SI-S-SZ od Kuline sv. Bartola između Kožina i Petrčana, s obzirom na to da se zemljišta ponad nje i danas nazivaju Brajde Ardanića (Jordanića). Jakovica, udova Šimuna Jordanića, dala je tu šumu s pašnjakom (nemus) 28. lipnja 1545. godine u svoje ime i ime svojih sinova u koncesiju na godinu dana redovnicima sv. Krševana u Zadru, za obnovu samostana, na kojoj su redovnici podigli vapnenicu. Ta su zemljišta sredinom 16. stoljeća naznačena kao vlasništvo Nikole Jordanića i njegova brata Augustina, vjerojatno Jakovičinih sinova. Oni su 14. ožujka 1557. godine dali ad pastinandum ac plantandum Stjepanu iz Kotora, težaku i stanovniku Zadra i njegovu nećaku Raški (Raschi) dva gonjaja zemljišta deri positi in pertinentiis Villae Peterzane, a parte sirocali ecclesie Sancti Bartholomei infra hos confines: De siroco iura monasterii Sanctae Catherinae Jadre de trauersa iura monasterii Sanctae Mariae de Jadra de quirina nemus dictorum fratrum de Jordano et de borea iura domini Gregorii clerici et Vincentiis Hmelcouich fratrum de Jadra. Težaci su se obvezali o svom trošku dovesti četvrtinu prinosa bilo in portu Sanctae Sabinae aut Sancti Bartholomei. HR-DAZD-31, Simon Budineus (1556. - 1599.), b. I, fasc. I, fol.; usp. HR-DAZD-336, Benediktinski samostan sv. Krševana Zadar (918. - 1806.), kut. 6, fasc. 2.3.6.17, br. 6, S̆. LJUBIĆ, »Dva popisa listina«, str. 161

${ }^{156}$...che la uigna altra uolta lauorata per detto Chacinouich sopra il terreno delle dette Reuerende Monache posto in detto luoco di Peterzane sopra il Castel di Bruscandoli in loco detto Draga. HR-DAZD-338, Samostan sv. Dominika, kut. 3, br. 61c, fol. 14; HR-DAZD-338, Samostan sv. Dominika, Regesta pergamena, br. 579.

${ }^{157}$ Obitelj Hmeljković (Bruscandolo) posjedovala je zemljište poco lontano dalla uila Bartolac aratorio et parte oliueri uerso siroco, kojemu je sa SI graničilo zemljište sv. Katarine, što se vjerojatno odnosi na Milutinovićevu zemljišnu česticu. HR-DAZD-338, Samostan sv. Dominika, kut. 3, br. 61c.

${ }^{158}$ HR-ASSMZD, Inventario, fol. 4r.
} 
je južno od današnje nove ceste Zadar - Nin, istočno od Gornjih Petrčana. ${ }^{159} \mathrm{Na}$ istom položaju zabilježen je najvjerojatnije neiskoristiv ostatak krševita tla. Na Grusini je bilo položeno zemljište za koje je naznačeno da se nalazilo iznad vode, JI od sela i kaštela, a SI od zemljišta koje je obrađivao Milutinović. SI od toga zemljišta, bilo je položeno još jedno zemljište. Sveukupno je Čačinović obrađivao 27 gonjaja, jednu kvartu i 46 pertika samostanskoga posjeda. ${ }^{160}$

Nastamba Petra Devenešića bila je veličine 54 pertike, a uz nju je bio vrt. Devenešić je posjedovao vrtove na položaju Grusine, koji su sa SZ graničili sa selom (contiguo da prouenza della uilla). Ispod vrta prostirala se podvornica, a SZ od vrta ispod podvornice prema selu komad zemljišta. Devenešić je obrađivao zemljište SI od novoga zgona, čiji je jedan dio bio položen SZ sve do granica samostanskoga posjeda sv. Marije u Zadru. Devenešićev maslinik bio je položen na granici s Kožinom, ispod i SZ zemljišta koje je obrađivao Ivan Paić. Uz to, na mjestu starih vinograda »stralassate del detto Piero« (Devenešić), koji su graničili »da prouenza e Borra Bruscandolo, da sirocco Batista Barbiricich, da gherbin Bosco del Jordanich mediate uia publica«, Paić je obrađivao oranicu s maslinikom te još jedno zemljište SZ od nje. ${ }^{161}$ Na položaju Pod Grabar (sotto Grabar) prostiralo se Devenešićevo zemljište. Jednako je obrađivao komad zemljišta SI, SZ i JI od drage Bruscandola (ualle Bruscandola), a SZ od zemljišta u posjedu samostana sv. Marije. Iznad položaja Vrbice Devenešić je obrađivao dva zemljišta kako slijedi: SI od zdenca Vrbice i S od Vrbice, a SI od zemljišta koje je obrađivao Mate Diklić. U Grusinama je Devenešić uživao dva povezana zemljišta, od kojih je jedno bilo položeno JI od drugoga. SI od toga zemljišta Devenešić je obrađivao komad ugaonog zemljišta, na sjecištu poljskih puteva (una cantonada del ditto terreno). U Grusinama se prostirao zemljišni teren, koji je bio položen JJI od sela, a graničio je s poljem u dragi Vrbica (della campagna della ualle di Verbiza), SZ od gaja (gaio), ${ }^{162}$ a zemljište je bilo kamenito i slabe kvalitete (catiuo e saxoso). Sveukupno je Petar Devenešić obrađivao 24 gonjaja, dvije kvarte i 96 pertika zemljišta u posjedu samostana sv. Katarine u Zadru. ${ }^{163}$

Mate Pavić je nanovo pripremio vrt u Grusinama, koji se nalazio SZ i S od sela, a graničio je SI s vrtom Ivana Čačinovića. Drugi Pavićev vrt bio je položen SZ s gornje strane puta (da gherbin oltra la strada), a JI od zemljišta Mate Diklića. Pavić je obrađivao komad zemljišta koji se prostirao SI od kaštela u Grusinama (da borra del Castel in Grussine). Osim Pavića, na tom položaju obrađivao je komad zemljišta Andrija Grubatović, koji je stanovao u kaštel Bruscandolu (Castel del Bruscandolo). ${ }^{164}$ Tablično se prikazuje površina zemljišta koja su u blizini i oko kaštela i sela (villa) samostana sv. Katarine u Gornjim

\footnotetext{
${ }^{159}$ Tome u prilog navodi se da je položaj Čačinka naveden u k.o. Petrčane kao k.č. 380, a kao i u slučaju položaja Viševice, i ovdje je zabilježen postupak naknade za oduzetu imovinu samostana benediktinki sv. Marije u Zadru.

${ }^{160}$ HR-ASSMZD, Inventario, fol. 4v.

${ }^{161}$ Isto, fol. $5 \mathrm{r}$.

${ }^{162}$ Toponim Gaj do danas je sačuvan na tom položaju, kao i Drage; južno od njih je smješten položaj Vrbice. Geomorfološke i pedološke značajke tla podudaraju se s opisom iz isprave, jer je doista riječ o krševitom području.

${ }^{163}$ HR-ASSMZD, Inventario, fol. $5 \mathrm{v}$.

${ }^{164}$ Isto, fol. 6 r.
} 
Petrčanima obrađivali pojedini koloni, a podijeljena su na zemljišta u polju i ona u Grusinama (Tablica 1).

Tablica 1. Površina zemljišta petrčanskih kolona u Grusinama i Polju, izražena u gonjajima $(G)$, kvartima $(K)$ i pertikama $(P)$.

\begin{tabular}{|c|c|c|c|c|c|c|c|c|c|c|c|c|c|c|c|}
\hline Koloni & \multicolumn{3}{|c|}{ Ivan Paić } & \multicolumn{3}{|c|}{ Ivan Milutinović } & \multicolumn{3}{|c|}{ Mate Diklić } & \multicolumn{3}{|c|}{$\begin{array}{c}\text { Ivan Čačinović i } \\
\text { Mate Pavić }\end{array}$} & \multicolumn{3}{|c|}{ Petar Venešić } \\
\hline Površina & G & $\mathbf{K}$ & $\mathbf{P}$ & $\mathbf{G}$ & $\mathbf{K}$ & $\mathbf{P}$ & $\mathbf{G}$ & K & $\mathbf{P}$ & G & $\mathbf{K}$ & $\mathbf{P}$ & $\mathbf{G}$ & $\mathbf{K}$ & $\mathbf{P}$ \\
\hline Polje & 11 & 3 & 29 & 12 & 3 & - & 14 & 2 & 34 & 15 & - & 25 & 13 & 3 & 90 \\
\hline Grusine & 17 & 3 & 97 & 7 & - & 53 & 4 & - & 68 & 12 & 1 & 21 & 10 & 3 & 6 \\
\hline Ukupno & 29 & 3 & 6 & 19 & 3 & 53 & 18 & 3 & 2 & 27 & 1 & 46 & 24 & 2 & 96 \\
\hline
\end{tabular}

Osim tih zemljišta, koja su tvorila kmetske jedinice (ždrijebove), ${ }^{165}$ u Petrčanima su Nikola Žila (Xilla), koji je stanovao u kaštelu Melkovica (Melcouicca), ${ }^{166}$ i Ivan Čačinović obrađivali mladi vinograd na položaju Orišac sjeverno od zdenca, koji je graničio »da siroco Simon Gliubaucich, da borra Bruscandolo, da gherbin parte le raggioni di Santa Maria, parte l>ospedal di San Bernardin, da prouenza le raggioni delli Reuerendi frati di San Grisogono ${ }^{167}$. Naznačeno je da da je taj vinograd prvotno premjerio (pertigado) pok. kapetan Bartolomej de Marchi. ${ }^{168} \mathrm{~S}$ obzirom na to da su na tom području zabilježena zemljišta u vlasništvu samostana sv. Krševana i hospitala sv. Bernardina u Kožinu, ${ }^{169}$ zasigurno je bila riječ o graničnom području između posjeda Kožino i posjeda Petrčane, što potvrđuje i naznaka Bruscandolijevih posjeda, ${ }^{170}$ za koje je utvrđeno da su bili u vlasništvu Bartulca. Usto je na tom položaju do danas zabilježen toponim Frataština, što je moguće izvedenica iz talijanskoga izraza za redovnike (frati). U fondu samostana sv. Krševana u Zadru zabilježeno je vinorodno zemljište veličine šest gonjaja u vlasništvu samostana smješteno »sotto Gai chiamata Fraterschina in Villa di Glupavci«, koje je graničilo sa SI i

\footnotetext{
${ }^{165}$ Treba uzeti u obzir da zadarski agrar nije poznavao velike, cjelovite površine obradiva zemljišta, pa je općenita usitnjenost zemljišnog vlasništva uvjetovala i strukturu posjeda. Zemljoposjed je činio skup manjih zemljišnih cjelina koji su bili razbacani po svim dijelovima distrikta. Zemljoposjed ili villa sastojala se najčešće od više ždrijebova, a ždrijeb (površina od oko 7 hektara) gotovo nikad nije bio jedinstvena cjelina, nego je $\mathrm{i}$ on redovito razbijen na više manjih parcela ili pecia. T. RAUKAR, Zadar uXV. stoljeću, str. 166.

${ }^{166} \mathrm{Na}$ popisu stanovništva iz 1610. godine Nikola Žila naznačen je kao stanovnik Bartulca (San Bartholomeo), pa je moguće da se današnja Kulina na tom položaju nazivala u 16. stoljeću i kaštel Melkovica, prema hrvatskoj inačici prezimena Bruscandolo - Hmeljković, Milković. Usp. Z. DUNDOVIĆ, »Popis stanovništva«, str. 294.

${ }^{167}$ Položaj Orišac spomenut je u spisima samostana sv. Krševana: ...positum in pertinentis Peterzane loco uocato Orisaz. HR-DAZD-336, Benediktinski samostan sv. Krševana Zadar (918. - 1806.), kut. 6, fasc. 2.3.6.17, br. 16; S̆. LJUBIĆ, »Dva popisa listina«, str. 162.

${ }^{168}$ HR-ASSMZD, Inventario, fol. 7r.

${ }^{169}$ Stjepan Gunjača naveo je da je 27. kolovoza 1509. godine samostan sv. Marije dao u trogodišnji najam zemljišta hospitala sv. Bernardina u Kožinu, s obzirom na to da su redovnice sv. Marije, zajedno s redovnicama sv. Nikole u Zadru upravljale hospitalom. S. GUNJAČA, »Repertorium actuum«, str. 314.

${ }^{170} \mathrm{U}$ opisu Bruscandolijevih posjeda na tom području samo je za jednu česticu naznačeno da je graničila $\mathrm{s}$ posjedima sv. Krševana: Un pezzo di tereno de gogniali 12 in circa aratorio da maestro $S$. Maria, da garbin San Grisogono uignie, da bora colina saso uiuo, da siroco $S$. Catarina. Opisi granica i kvalitativna oznaka zemljišta idu u prilog gornjem zaključku. Usp. HR-DAZD-338, Samostan sv. Dominika, kut. 3, br. 61c.
} 


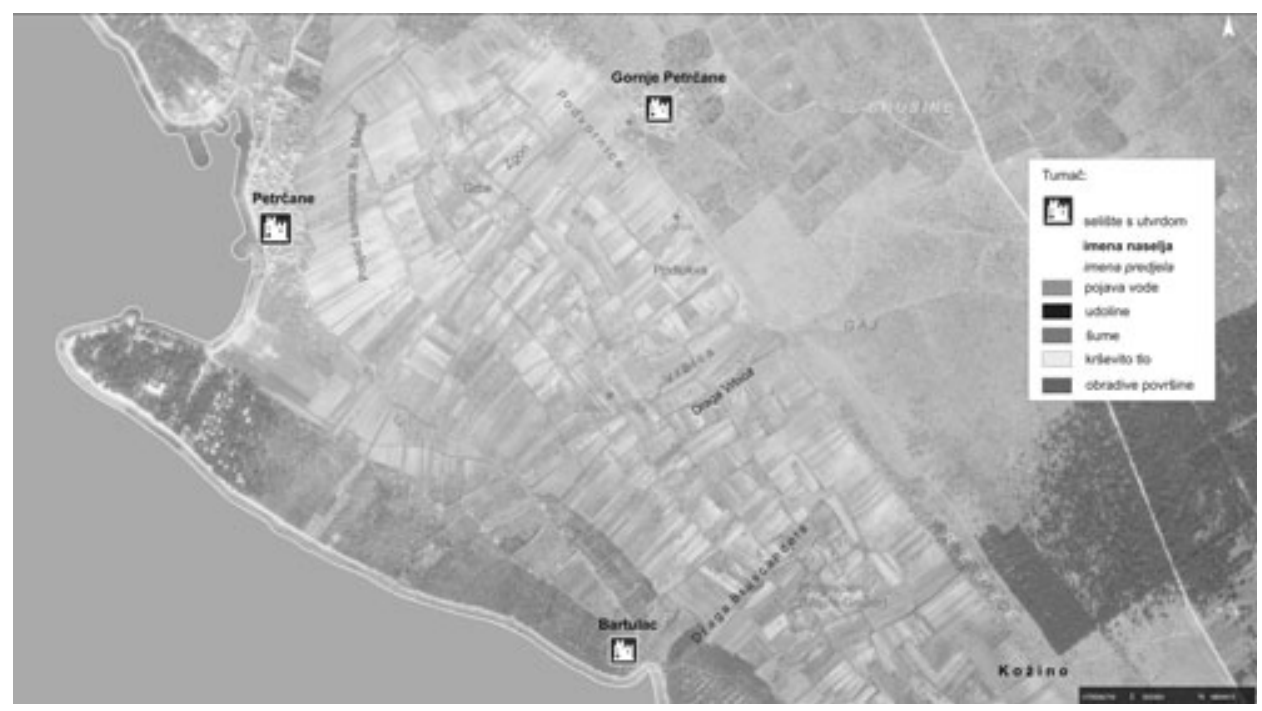

Slika 8. Geografska imena na posjedu samostana sv. Katarine iz 16. stoljeća

JI sa samostanom sv. Katarine, a dijelom sa SI i sa SZ i JZ sa samostanom sv. Marije. Položaji Podgajnice (sotto Gai) i Frataština do danas se prostiru nadomak sela Kožina, prema JZ, iznad kojih je položaj Brnestrice, na kojem se prostirala zemljišna čestica kolona Čačinovića (danas Čačinovka). Podatak je važan jer svjedoči da su se zemljišta samostanske ville u 16. stoljeću protezala sve do današnjega Zapadnoga puta u Kožinu, odnosno da su u posjedovnom smislu potpadali pod selo Glupavce (Gornje Petrčane). ${ }^{171}$

Nikoli Žili pripadao je dio vinograda JI od Ivana Čačinovića. Mate Pavić sam je obrađivao stari zgon (sgon uechio), koji su ostali koloni napustili. ${ }^{172}$ Novi zgon (sgono nouo) obrađivali su svi koloni, a bio je smješten ispod lokve (sotto l'agua). ${ }^{173} \mathrm{Na}$ istom položaju prostirala se špetica. ${ }^{174}$ Konačno, na temelju podataka iz izvornika i današnjih imena pojedinih predjela na području između Petrčana, Gornjih Petrčana, Bartulca i Kožina prilaže se karta s prijedlogom označenih najvažnijih toponima iz 16. stoljeća, čiju podlogu čini ortofoto karta iz 1968. godine, na kojoj je razvidno da su zemljišne čestice na tom području tada još uvijek bile redovito i marno obrađivane, a prostirale su se sve do granica Dikla (Slika 8).

${ }^{171}$ U opisu posjeda samostana sv. Krševana s početka 18. stoljeća stoji: Peterzane. Gognali sei, et mezzo in circa vigna, nominata Sotto Gai, chiamata Frateschina in Villa di Glupavce villa distinta da Peterzane, ma in spirituale sotto Peterzane, il giudice della quale serve anco per Glupavce, et perciò come sotto nome di Peterzane. HR-DAZD-336, Benediktinski samostan sv. Krševana Zadar (918. - 1806.), kut. 6, fasc. 2.1.4, fol. 8r.

${ }^{172}$ Uporabom alata za mjerenje površine na portalu Državne geodetske uprave na položaju Zgon dobiva se površina od oko $9.800 \mathrm{~m}^{2}$, što odgovara prostornoj površini izraženoj u gonjajima, kvartama i pertikama.

${ }^{173}$ Moguće je da je to današnji položaj smješten u polju JI od Gornjih Petrčana, na kojem su zemljišne čestice Dugi i Kratki zgon, ispod položaja koji se danas naziva Podlokva odnosno Lokve, što je hidronim proizišao iz talijanskoga pojma za vodu l'acqua. Usp. Siniša VUKOVIĆ, »Onomastička terminologija - Inventar termina i stratifikacija onomastike kao prilog teoriji imenoslovlja u cjelini«, Čakavska rič, god. 35, br. 1, Split, 2007., str. $163,171$.

${ }^{174}$ HR-ASSMZD, Inventario, fol. 7r. 
Na sljedećoj slici, na podlozi ortofoto karte iz 2017. godine, označeni su toponimi koji su spomenuti u radu i spisima iz 16. stoljeća, a imena su im zadržana do danas (Slika 9).

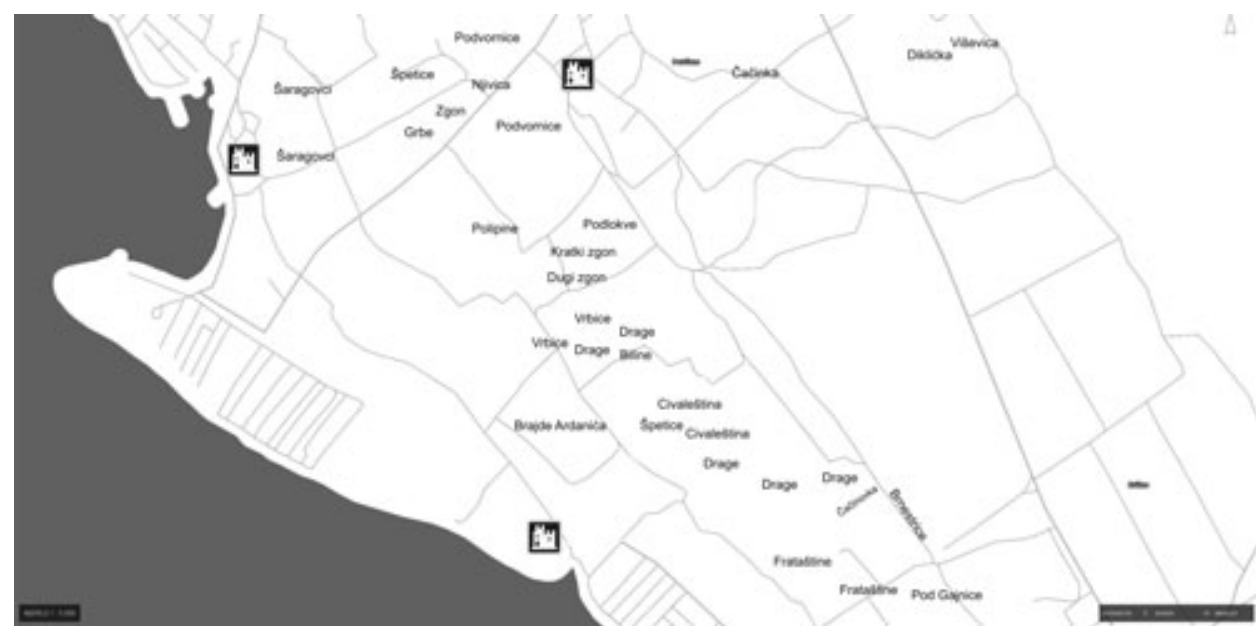

Slika 9. Moderni toponimi koji su spomenuti u radu

\section{Samostanski posjedi u Diklu i Kožinu}

Dana 16. svibnja 1590. godine samostanski pisar Bartol Loccadello zabilježio je prema naputku opatice Venture Ventura izmjerene posjede samostana sv. Katarine u Diklu, odnosno ispod Kožina (sotto Coxinosello). Riječ je o posjedima Kože Saladina koji su od kraja 14. stoljeća u vlasništvu samostana sv. Katarine, a polovinom 15. stoljeća opisane su granice manjeg komada zemlje u Petrčanima: »...de sirocco et traversa monasterium S. Grisogoni de Jadra, de borea monasterium S. Catarine, de quirina plebania S. Petri de Petrzane ${ }^{175}$. N. Jakšić dokazao je da toponimi Kožino Selo i Petrčane, uz koje se spominje crkvica sv. Petra u srednjovjekovlju, označavaju isti referent, ${ }^{176}$ što se očito primjenjivalo i u kasnijim ispravama. ${ }^{177}$

\footnotetext{
${ }^{175}$ Nikola JAKŠIĆ, »Kult sv. Petra«, str. 325.

${ }^{176}$ Isto, str. 326.

${ }^{177} \mathrm{U}$ ispravi od 10. prosinca 1556. godine prior samostana sv. Krševana Bernardin daje ad plantandum ac pastinandum Mati Bumbi zvanome Ratković, stanovniku Zadra, gognalia quinque in circa terreni deri positi in pertinentiis Villae Peterzane, a on se obvezao podići vinograd u roku od četiri godine te nakon desete godine (1567.) podavati četvrtinu prinosa koje je morao o svom trošku dovesti na dogovoreno mjesto ispod crkve sv. Petra u današnjem Diklu (loco dicto subtus Sanctum Petrum), gdje se prior samostana obvezao čekati s barkom za ukrcaj plodina. Naznaka crkve sv. Petra kao mjesta ukrcaja plodina implicira da se izraz pertinentiis Villae Peterzane odnosi na zemljišta u Kožinu. Istim izrazom - pertinentiis Villae Peterzane - označena su zemljišta u Petrčanima kod Bartulca (vidi bilj. 104), s tom razlikom što su koloni dominikal dovozili u petrčansku luku ili luku Sv. Bartula (in portu Sanctae Sabinae aut Sancti Bartholomei). HR-DAZD-31, Simon Budineus (1556. - 1599.), b. I, fasc. I, fol. 4r.
} 
Sveukupno je samostan na tom području posjedovao pet zemljišnih terena, različitih površina, ukupne veličine 32 gonjaja, 12 kvarti i 265 pertika. ${ }^{178}$ Martin Rimanić iz Dikla ${ }^{179}$ obrađivao je samostanski vinograd, koji je bio smješten iznad crkve sv. Petra u Diklu. ${ }^{180}$ SI uz taj vinograd graničilo je obradivo zemljište (terreno aratorio), koje su u najam uzeli težak Ivan Surotva iz zadarskoga Varoša i mistro Šimun Slipčić. ${ }^{181}$ Dijelom je bilo pod oranicom, dijelom pod vinogradom i maslinikom, a dijelom pod šumom i nekultivirano. Zemljište se prostiralo u dragi podno brda (tutta la ualle sotto il monte), koje danas čini granicu između naselja Kožina i Dikla. Na tom području danas se prostire položaj Dikljanski Brig, a šuma odnosno položaj koji se SZ od Briga proteže sve do današnjega kožinskog groblja naziva se Katarišćina, moguće prema posjedima samostana sv. Katarine.

JZ od toga zemljišta mistro Šimun Slipčić obrađivao je vinograd i maslinik, čije su granice bile: »da borra e siroco la plouania di San Piero; da prouenza Fumatichii; ${ }^{182}$ da gherbin il gaio ouer bosco fino al mar; da siroco e prouenza sonno le ualle«. U tim granicama danas se prepoznaju položaji Plovanije, Primorje i Duboke Drage S i SZ od crkve sv. Petra, koja se u ispravama nerijetko pozicionira pod Petrčane. Primjerice, u ispravi od 20. srpnja 1557. godine zadarski kanonik Santo de Santi zabilježen je kao »rector capellae siue simplicis beneficii Sancti Petri loci dicti Peterzani diocesis Jadrensis«. On je dao ad arrandum, seminandum ac cultiuandum Martinu Marojiću i Martinu Radniću iz Kožina sva zemljišta u vlasništvu kapele sv. Petra »de Peterzane partem dera, et inculta, et partim arratoria et laboratoria iacentia in loco predicto Peterzane in pertinentiis dictae cappellae «. ${ }^{183}$ Kanonik de Santi bio je u posjedu tih dobara i 1564. godine. Bila je riječ o ukupno 50 gonjaja zemljišta, od čega osam gonjaja oranica, 10 gonjaja vinograda i maslinka te ostatak šumovitoga i neiskoristivoga tla. Zemljišta su dana na obrađivanje udruženicima (sozzal), koji su ih bili dužni kultivirati u roku od osam godina, a devete godine davati dominikal u iznosu od $1 / 4$ prinosa. Crkva sv. Petra naznačena je u ispravi kao poljska kapela bez dušobrižništva (capella campestre sine cura). De Santi je naglasio da su velike štete na tom posjedu činili stratioti, ${ }^{184}$ koji su te godine zapalili obližnju šumu i maslinike, a nerijetko su se penjali

\footnotetext{
${ }^{178}$ HR-ASSMZD, Inventario, fol. 8 r.

${ }^{179}$ Naznačen kao nositelj domaćinstva na popisu iz 1610. godine. Z. DUNDOVIĆ, »Popis stanovništva«, str. 293.

${ }^{180}$ O crkvi vidi kod: I. PETRICIOLI, »Tri romaničke crkve u Diklu«, str. 176-177; Nikola JAKŠIĆ, »Kult sv. Petra«, str. 321-324.

${ }^{181}$ Riječ je o postolaru Šimunu Slipčiću iz Zadra, koji je tijekom apostolske vizitacije Zadarske nadbiskupije iz 1579. godine zabilježen kao svjedok o pitanju odvođenja u ropstvo kršćana od strane Osmanlija. IT-AAV, Congr. Vescovi e Regolari, Visita Ap. 78, Jadrensis, fol. 109v.

${ }^{182}$ Vjerojatno je riječ o posjedima zadarske i hvarske plemićke obitelji Fumatis, čija je brojnost zemljišnih posjeda sve izraženija od početka 16. stoljeća na zadarskim otocima, ali i u blizini grada (današnje Kolovare, Kožino, Paprat, Bibinje, Diklo...). Vidi više na poveznici http://hbl.lzmk.hr/clanak.aspx?id=6474 (posjet ostvaren 24. lipnja 2020.). Njihovi su posjedi spomenuti 1509. godine: ...sopra fondi delli signori fratelli de Fumatis in Cosino in loco presso San Piero. S. GUNJAČA, »Repertorium actuum«, str. 337.

${ }^{183}$ HR-DAZD-31, Simon Budineus (1556. - 1599.), b. I, fasc. II, fol. 63v.

${ }^{184}$ Nazočnost lake konjice (stratioti) na tom području zorno svjedoči o stalnoj opasnosti od osmanskih upada (vidi bilj. 87.), napose martolosa, u mirnodopskim uvjetima tijekom 16. stoljeća, ali moguće i od upada uskoka. O tome više kod: Lovorka ČORALIĆ, „»"Benemerita nazione“: albanski vojnici i časnici u Zadru (XVI. - XVIII. stoljeće«, Zbornik Odsjeka za povijesne znanosti Zavoda za povijesne $i$ društvene znanosti $H A Z U$, vol. 27, Zagreb, 2009., str. 121-164; Aladin HUSIĆ, »Vojne prilike u splitsko-zadarskome zaleđu u 16. stoljeću - (osmanski serhat 1530. - 1573.) «, Prilozi za orijentalnu filologiju, vol. 56, Sarajevo, 2007., str. 125-144; Nada ZEČEVIĆ, »Restoration, Reconstruction and Union: memories of home in the stratiot poetry
} 
na crkveno krovište zbog lova na vrapce (caligeti), pri čemu bi ga oštetili, a običavali su zapaliti i vrata na crkvi sv. Petra i otuđiti željeznu bravu. ${ }^{185}$

Marko Šumić (Sumich) i Puse iz Kožina ${ }^{186}$ zajedno su obrađivali komad zemljišta koji je graničio »da gherbin parte l>ospedal, parte San Nicolo, da prouenza Meser Batista Panizon $\ll \cdot{ }^{187} \mathrm{Na}$ istom položaju bile su posječene tri masline, uz zemljište, koje je obrađivala Mara Pirijho (?) iz Dikla, a nekada ih je obrađivao Nikola Mandić. ${ }^{188}$ Samostan je kod male vode (l'agua pizola) posjedovao 7135 pertika zemljišta, za koje nisu navedeni obrađivači ni kvalitativna oznaka tla. ${ }^{189}$

Dana 25. kolovoza 1596. godine pisar Loccadelo zabilježio je samostanske posjede sv. Katarine u Kožinu, prema naputku opatice Donate Britanico, a zemljišta je izmjerio Kristofor Ventura. Posjedi u Kožinu prešli su u vlasništvo samostana sv. Katarine koncem 14. stoljeća oporukom Pelegrine Saladin, po čijem je ocu Koži (Cosa, Coxa) selo i nazvano Kožino Selo, a bilo je dio Saladinovih posjeda u južnom dijelu srednjovjekovnih Petrčana. ${ }^{190}$ Uglavnom je bila riječ o vinogradima i pašnjacima. Vinograde u Kožinu obrađivao je težak Puse. On je u blizini Kožina obrađivao jedan stari vinograd. JI od njega prostirao se drugi vinograd, koji je obrađivao njegov brat Mihovil. Sjeverno od javnoga puta kojim se išlo prema selu prostirao se vinograd veličine 1800 pertika, a SZ od njega je Puse obrađivao komad zemljišta.

Seoskom župniku benediktinke su dale u najam iskrčeno zemljište (pastino del prete) na položaju Brnestrice. Uz tu krčevinu, benediktinke su posjedovale komad nekultuviranoga tla veličine 154 pertike. Na župnikovu zemljištu Puse je obrađivao 266 pertika zemlje, a sam je uživao krčevinu na položaju Brnestrice veličine 468 pertika. JZ od Pusine krčevine

of Antonio Molino«, Radovi Zavoda za hrvatsku povijest Filozofskoga fakulteta Sveučilišta u Zagrebu, vol. 51, br. 1, Zagreb, 2019., str. 163-180; S. M TRALJIĆ, »Zadar i turska pozadina«, str. 210.

${ }^{185}$ IT-ASVe, Sopraintendenti alle decime del clero, pezzo 39, br. 84.

${ }^{186} \mathrm{Na}$ popisu stanovništva iz 1610. godine upisano je nekoliko nositelja domaćinstava u Kožinu s prezimenom Pussich. Tu se prepoznaje ishodište današnjega kožinskog prezimena Puhalović. Prema kazivanju lokalnoga stanovništva Puhalovići se i danas nazivaju nadimkom Pujsini, što je moguće dovesti u izravnu vezu s težakom Pusom iz Kožina, čija su braća Mihovil i Jurašin također spomenuta u izvornicima. Usp. Z. DUNDOVIĆ, »Popis stanovništva«, str. 293.

${ }^{187}$ Battista Pannizoni bio je bogati zadarski trgovac, koji se često spominje u kupoprodajnim ugovorima u drugoj polovini 16. stoljeća. Godine 1577. kupio je oko šest gonjaja vinograda i maslinika te dio oranice in loco uocato Cosino Sello infra hos confines a siroco iura Venerabilium Dominarum Monialium Sanctae Mariae Jadre, a trauersa iura Venerabilium Dominarum Monialium Sanctae Catharinae, a borea iura Nobilium de Nassis, et a quirina iura predicti Nobili de Nassis mediante uia publica. HR-DAZD-31, Laurentius de Martinis (1576. - 1585.), b. unica, neozn. folija.

${ }^{188}$ Jedna od draga koja se prostire između Kožina i Petrčana naziva se i danas Mandića draga, odnosno Draga Mandićka. Moguće je da ima neke poveznice s prezimenom težaka Nikole Mandića. Čini se da je riječ o Nikoli Mandiću (Mandacalouich) iz Dikla, koji je 1567. godine u Kožinu kupio (emptio) dva gonjaja vinograda od samostana sv. Katarine. U kontekstu lokalnih migracija Nikolu Mandića je moguće povezati s rodom Mandića iz Novigrada koji se tamo spominju u 15. stoljeću. Naime, u Novigradu su zabilježeni pripadnici obitelji Mandić s jednakim dodatkom prezimenu Mandecalo, primjerice Matheo Mandich Mandecalo de Nouigradi 1532. godine i Gregorius Mandachalo de castro Nouigradi 1547. godine (zahvaljujem Ivni Anzulović na ustupljenom podatku). Usp. HR-DAZD-31, Simon Mazzarellus (1555. - 1589.), b. I, fasc. XII, neozn. folija; HR-DAZD-31, Jeronymus Ravagninus (1516. - 1532.), b. I, fasc. XII, 17. 4. 1532.; HRDAZD-31, Petrus de Bassano (1531. - 1570.), b. I, fasc. II, 21. 11. 1547.

${ }^{189}$ HR-ASSMZD, Inventario, fol. $7 \mathrm{v}$.

${ }^{190}$ Usp. N. JAKŠIĆ, »Kult sv. Petra«, str. 324-326; Emil HILJE, »Imena zadarskih plemićkih porodica u kasnosrednjovjekovnoj toponimiji zadarskoga kraja«, Folia onomastica Croatica, br. 4, Zagreb, 1995., str. 72-73. 
prostirala se oranica u vlasništvu samostana, pod korovom (pien di erba), koju nitko nije obrađivao. SI od nje, a iznad Pusina zemljišta prema SZ, prostirao se komad zemljišta veličine 4368 pertika. Sveukupno je u Kožinu samostan posjedovao 13 gonjaja, tri kvarte i 31 pertiku zemljišta. ${ }^{191}$ Razvidno je, dakle, da je samostan sv. Katarine u Kožinu i Diklu posjedovao zemljišne čestice, koje su bile dane isključivo u težaštinu, za razliku od posjeda u Petrčanima, koji je dan u kolonat. ${ }^{192}$ Međutim, nije isključeno da su ranije (u srednjem vijeku) koludrice sv. Katarine u Kožinu posjedovale ždrijebove zemlje jer je u samostanskim spisima zabilježeno da su 11. listopada 1556. godine sva zemljišta u Kožinu dana u najam Jakovu Maričiću i Jurju Seršiću (Sersich) iz istoga sela, osim zemljišta na zgonu (sgono), koja su bila položena ispod sela na položaju Dolac, ${ }^{193}$ a u izvješću iz 1564. godine spomenut je ždrijeb zemlje. ${ }^{194}$ Zemljište ispod Kožina, podno Puta Lokve, danas se naziva Zgon, a zemljišta zapadno od Zgona, prema Putu Primorja nose ime Doca (Dolac), što odgovara opisu samostanskih posjeda u Kožinu iz 1556. godine.

\section{Samostanski posjedi na Ugljanu}

Samostan sv. Katarine posjedovao je zemljišne čestice i u naselju Ugljan na istoimenome zadarskom otoku. Ivna Anzulović obradila je podjelu posjeda između zadarskih plemića Jerolima Grizogona ili Bartulačića pok. Antuna i braće Detrešić Grgura i Alojza pok. Alojza u Lučinu selu (zaselak Ugljana), što ju je 1576. godine izvršio ninski i paški plemić Juraj Kašić. Tu je naznačeno da su redovnice sv. Katarine imale zemlju na položaju Vela njiva, JZ od Bartulačića. Položaj se sačuvao do danas jugoistočno od položaja na kojem se nekada nalazila crkva sv. Ivana u Lučinu Selu. ${ }^{195}$ Taj je položaj zabilježen još 1521. godine u samostanskim računskim knjigama kao vlasništvo koludrica sv. Katarine, zajedno s ostalim zemljišnim česticama na Ugljanu. ${ }^{196}$ Usporedbom izvješća o samostanskim posjedima na Ugljanu iz Državnoga arhiva u Veneciji i Venturina izvješća koji se ovdje razmatra, razvidno je da su posjedi samostana sv. Katarine na Ugljanu bili znatno veći koncem 16. stoljeća.

Kristofor Ventura giudice diuisor eletto per le Reuerende Monache di Santa Chatarina izvršio je 1590. godine podjelu između koludrica sv. Katarine, zadarskoga plemića dr. Franje Rose i braće Šimuna i Bartolomeja de Marchi (fratelli di Marco), ${ }^{197}$ jer su koludrice

\footnotetext{
${ }^{191}$ HR-ASSMZD, Inventario, fol. 8v.

${ }^{192} \mathrm{O}$ razlikama između težaštine i kolonata u dalmatinskom agraru vidi opširnije kod: Tomislav RAUKAR, Zadar u XV. stoljeću. Ekonomski razvoji i društveni odnosi, Zagreb, 1977, str. 80-104.

${ }^{193}$ HR-ASSMZD, Inventario, fol. 25r.

${ }^{194}$ In uilla Cosino Selo una sorte di terre lauorata per uno uilan al quarto. IT-ASVe, Sopraintendenti alle decime del clero, Zara. Monastero di S. Catherina di Zara, pezzo 39, br. 72.

${ }^{195}$ Ivna ANZULOVIĆ, »Lučino selo na otoku Ugljanu u drugoj polovici 16. st.«, Prošlost $i$ sadašnjost otoka Ugljana Šime BATOVIĆ (ur.), Zadar, 2012., str. 446.

${ }^{196}$ HR-ASSMZD, Libro delle monache de Santa Catarina, sv. 2, fol. 57r.

${ }^{197}$ S. K. Sander-Faer svrstao je pripadnike obitelji de Marchi pod neplemićku elitu grada Zadra u 16. stoljeću, čije su ženske članice bile redovnice samostana sv. Katarine. Dio zemljišta na Ugljanu, koji je prvotno pripadao pok. Martinu de Marchiju zvanome Meštrović, samostan sv. Katarine dijelio je s braćom de Marchi, čije su sestre Frančeskina i Urša bile njihove redovnice. Usp. S. K. SANDER-FAES, Urban Elites of Zadar, str. 192-193, 206, bilj. 29; HR-ASSMZD, Inventario, fol. 11v.
} 
bile nezadovoljne podjelom koju je 1588. godine izvršio Juraj Kašić. Bila je riječ osobito o posjedima na položaju Krševo (Chreseuo). ${ }^{198}$ Razvidno je da je Juraj Kašić pri podjeli zakinuo djeljenike za više gonjaja zemljišta, zbog čega se prionulo novoj diobi.

Sredinom 16. stoljeća na otoku Ugljanu samostan benediktinki sv. Katarine bio je u posjedu zemljišta dijelom pod oranicom, a dijelom pod vinogradom, koji su obrađivala dvojica seljana (villici), a samostanu su davali dominikal u visini $1 / 4$ prinosa. ${ }^{199} \mathrm{U}$ drugoj polovici 16. stoljeća zabilježeno je da je posjed koludrica sv. Katarine na Ugljanu graničio s posjedom Šimuna de Marchija, koji je bio sjeverno od sela Sušice. Benediktinke sv. Katarine posjedovale su zemljište SI od sela Mirojić, a graničilo je kako slijedi »da siroco Monache di Santa Catarina, da prouenza Didichii, da gherbin Villa Maroichii mediante uia publica, da borra parte Meser Simon del Marco, e parte li detti diuisori $\ll{ }^{200}$ S posjedom Šimuna de Marchija na Ugljanu benediktinke sv. Katarine graničile su na položaju Ljokini (Gligliceuo). ${ }^{201}$ Jugoistočno od Koledišća (Coledischie) nalazio se de Marchijev posjed, s kojim su JZ i SZ graničile koludrice sv. Katarine. Benediktinke su uživale SI dio šume, koja se nalazila JI od crkve Svih svetih u Ugljanu. ${ }^{202}$

S obzirom na to da se naselje Ugljan svojim niskim i blagim reljefom razlikuje od ostaloga dijela otoka i kao takvo ima izvanredne uvjete za razvoj poljoprivrede, ono je u tom smislu bilo najvažniji dio otoka Ugljana, kako je zaključila I. Anzulović. ${ }^{203} \mathrm{Uz}$ to, s obzirom na nedostatak površina za uzgoj žitarica u zadarskom zaleđu osobito nakon Ciparskoga rata (1570. - 1573.) te činjenicu da je najveći dio zemljišta na Ugljanu bio pod oranicama, jasan je značaj toga dijela otoka u takvim okolnostima. ${ }^{204}$ Uzme li se to u obzir, a u kontekstu nezadovoljstva oko diobe koju je izvršio plemić Juraj Kašić i činjenice da su u drugoj polovici 16. stoljeća mnogi zemljoposjednici izgubili znatne površine obradivih čestica mletačko-osmanskim razgraničenjem, opravdano je postaviti pitanje jesu li plemići pri diobama zloporabili službu sudaca djelitelja? Naime, novom podjelom, koju je izvršio Kristofor Ventura, djeljenicima su pripale dodatne površine kako slijedi: Bartolomeju de Marchiju dva gonjaja, tri kvarte i 59 pertika, samostanu sv. Katarine tri gonjaja, tri kvarte i 60 pertika te Šimunu de Marchiju četiri gonjaja, jedna kvarta i 44 pertika. ${ }^{205} \mathrm{~S}$ obzirom na to da u toj diobi plemić Francesco Rosa nije spomenut među djeljenicima novih zemljišnih čestica, opravdano je pretpostaviti da je nezadovoljstvo zainteresiranih strana bilo usmjereno prema posjedima koji su u prvoj diobi dodijeljeni njemu, tim više što je sudac Ventura zapisao da je plemić Juraj Kašić bio u srodstvu s plemićem Rosa (suo barba) ${ }^{206}$ Plemićka obitelj Rosa svoj je zemljoposjed širila od posljednje četvrtine 13. stoljeća uglavnom prema granici

\footnotetext{
${ }^{198}$ O položaju Krševo/Krševa na otoku Ugljanu, kao i ostalim koji se u radu dalje spominju, opširno je zapisao Kristijan Juran. Kristijan JURAN, »Popis povijesnih toponima iz arhivske građe«, Toponimija otoka Uglja$n a$, Vladimir SKRAČIĆ (ur.), Zadar, 2007., str. 247-280.

${ }^{199}$ IT-ASVe, Sopraintendenti alle decime del clero, Zara. Monastero di S. Catherina di Zara, pezzo 39, br. 72.

${ }^{200}$ HR-ASSMZD, Inventario, fol. 10r.

${ }^{201}$ Usp. K. JURAN, »Popis povijesnih toponima«, str. 259.

${ }^{202}$ O crkvi Svih svetih u Ugljanu vidi kod: Emil HILJE - Sofija SORIĆ, »Spomenici srednjovjekovnoga graditeljstva na Ugljanu«, Toponimija otoka Ugljana, Vladimir SKRAČIĆ (ur.), Zadar, 2007., str. 107-108.

${ }^{203}$ I. ANZULOVIĆ, »Lučino selo«, str. 419-420.

${ }^{204}$ I. ANZULOVIĆ, »Lučino selo«, str. 449.

${ }^{205}$ HR-ASSMZD, Inventario, fol. 10v.

${ }^{206}$ Isto, fol. 9v.
} 
zadarske astareje (Murvica), a kasnije oprezno i u njezinu dubinu (Podi, Veterinići). ${ }^{207} \mathrm{~S}$ obzirom na to da je to područje mletačko-osmanskim razgraničenjem u drugoj polovici 16 . stoljeća potpalo pod osmansku upravu, vjerojatno je plemićka obitelj Rosa izgubila znatan dio svojih posjeda ili barem prihoda, ${ }^{208}$ zbog čega je usmjerila gospodarski interes na širenje relativno sigurnijih otočnih zemljoposjeda. ${ }^{209}$ Pojedinačni izvor, lišen metode kvantifikacije, ne pruža siguran odgovor na pitanje je li se pri diobama pogodovalo pojedincima ili institucijama. No, svojatanje zemljišta i česti sporovi zbog zemljišnih čestica na otoku Ugljanu nisu bile rijetkost ni među crkvenim zemljoposjednicima. ${ }^{210}$

Diobu između samostana sv. Katarine i zadarskih plemića nužno je promotriti kroz perspektivu običajnoga prava prema kojemu je vlasniku radne zemlje pripadalo i vlasništvo nad šumom i pašnjacima koji su uz nju bili vezani. ${ }^{211} \mathrm{~S}$ obzirom na to da se u zapisu na nekoliko mjesta spominju didići, autohtono otočno stanovništvo, može se zaključiti da su dobar dio šuma i pašnjaka spomenutih u diobi činili nekada nepodijeljeni i naslijeđeni zemljišni posjedi - didine - koji su kasnije prešli u ruke imućnijeg zadarskoga plemstva i građanstva. Kristijan Juran, koji je istraživao fenomen didića na zadarskim otocima, ${ }^{212}$ ustvrdio je da u historiografiji ta problematika nije temeljitije istražena. Za ovu raspravu važan je Juranov zaključak da „zadarsko plemstvo i crkvene institucije, naročito vrlo imućni i utjecajni samostani, okrupnjavanjem svoga otočnog posjeda postaju vlasnicima udjela u još nepodijeljenim šumama i pašnjacima, a poneki didići u toj se vlasničkoj strukturi još dugo drže « ${ }^{213}$. Tom zaključku u prilog ide dioba šume na Ugljanu između samostana sv. Katarine i zadarskih plemića Rosa i De Marchi, u kojem se didići konstantno spominju kao međaši navedenih posjeda.

Šume iz navedene diobe prostirale su se na nekoliko položaja. Bila je riječ o šumi SI od sela Sušice, čiji je jedan gonjaj JI od mula i vode (l'agua piscina $)^{214}$ ostao nepodijeljen, a graničio je sa sjevera s cantonadom vrta Lucije Grbinić, odakle se protezao do živoga kamena (a una pietra uiua) na kojem se nalazila kamenica (una Cameniza), odakle se nastavljao prema SI sve do kamenoga brežuljka, a potom je skretao SZ prema moru. ${ }^{215}$ U navedenoj kamenici prepoznaje se položaj Kamenica (Camenizza), koji je zabilježen u izvorima (su la cima del quale ui e una pietra detta Camenizza), ${ }^{216}$ čiji je naziv proizišao od male i plitke udubine na izdanku karbonatne stijene, koja je vjerojatno služila za napoj blaga. ${ }^{217}$ Ostatak šume

${ }^{207}$ T. RAUKAR, Zadar u XV. stoljeću, str. 129-130.

${ }^{208}$ S. M. TRALJIĆ, »Zadar i turska pozadina«, str. 214.

${ }^{209}$ Usp. S. SORIĆ, »Utvrđeni ljetnikovac obitelji de Soppe «, str. 48.

${ }^{210} \mathrm{O}$ tome vidi rad: Kristijan JURAN, »Zemljišni posjed zadarskih dominikanaca na otoku Ugljanu«, Toponimija otoka Ugljana, Vladimir SKRAČIĆ (ur.), Zadar, 2007., str. 75-99.

${ }^{211}$ K. JURAN, »Zemljišni posjed zadarskih dominikanaca«, str. 83.

${ }^{212}$ Vidi rad: Kristijan JURAN, »O didićima na zadarskom otočju u srednjem vijeku«, Miscellanea Hadriatica et Mediterranea, god. 2, br. 1, Zadar, 2015., str. 25-40.

${ }^{213} \mathrm{~K}$. JURAN, »Zemljišni posjed zadarskih dominikanaca«, str. 84.

${ }^{214}$ Apelativ pištavac ima mnogobrojne toponimijske odraze, od kojih se najveći broj odnosi na vrela. U nekim je toponimima došlo do značenjskog naslanjanja na dvije osnove: od pištati i pijesak jer voda na izvoru usitnjavanjem kamena stvara pijesak, pa i blato te je kod mnogih mikrotoponima tipa Pišćina, Pišcine, Pišćenica nemoguće odrediti prvotnu motivaciju. Dunja BROZOVIĆ RONČEVIĆ, »Nazivi za blatišta i njihovi toponimijski odrazi u hrvatskome jeziku«, Folia onomastica Croatica, br. 8, Zagreb, 1999., str. 40.

${ }^{215} \mathrm{HR}-\mathrm{ASSMZD}$, Inventario, fol. 11r.

${ }^{216} \mathrm{~K}$. JURAN, »Popis povijesnih toponima«, str. 252, bilj. 22.

${ }^{217}$ Zbog relativno nepovoljnih hidrogeografskih obilježja otoka Ugljana u ranijim se razdobljima koristila voda koja se zadržavala u obliku lokava, manjih najčešće prirodnih udubina koje su otočani uređivali, po potrebi i 
veličine 18 i 1/7 gonjaja i 71 pertike prostirao se s JI, a graničio je: s JI koludrice sv. Nikole u Zadru, s JZ selo Sušica, sa SZ dijelom more, a dijelom nepodijeljeno šumovito tlo. Tu je šumu samostan sv. Katarine dijelio sa zadarskim plemićima Rosa i De Marchi, s klauzulom da se zbog pristupa seoskom mulu (pristanu) i vodi između šume i sela Sušice ostavi javni put. I u drugim slučajevima dioba se podrazumijevalo da su mul i izvori vode na zemljišnim posjedima bili zajednički i nedjeljivi. ${ }^{218}$

Druga šuma nalazila se JZ od crkve Svih svetih, veličine 3 gonjaja i 60 pertika, a graničila je s JI sa zemljištem plemića De Marchi, s JZ sa zemljištem samostana sv. Katarine, sa SZ i SI s didićima. Šuma SZ od sela Sušice veličine jednoga gonjaja, koja se prostirala SZ od izvora vode, koji je bio u sredini valle di porto della villa Susizza nije se dijelila, nego su se sve tri strane njom slobodno služile zbog slobodnoga pristupa vodi. ${ }^{219}$ Da je doista bila riječ o pištavcu, potvrđuje činjenica da je na katastarskoj karti iz 19. stoljeća on ucrtan upravo u sredini uvale Sušica (Slika 10).

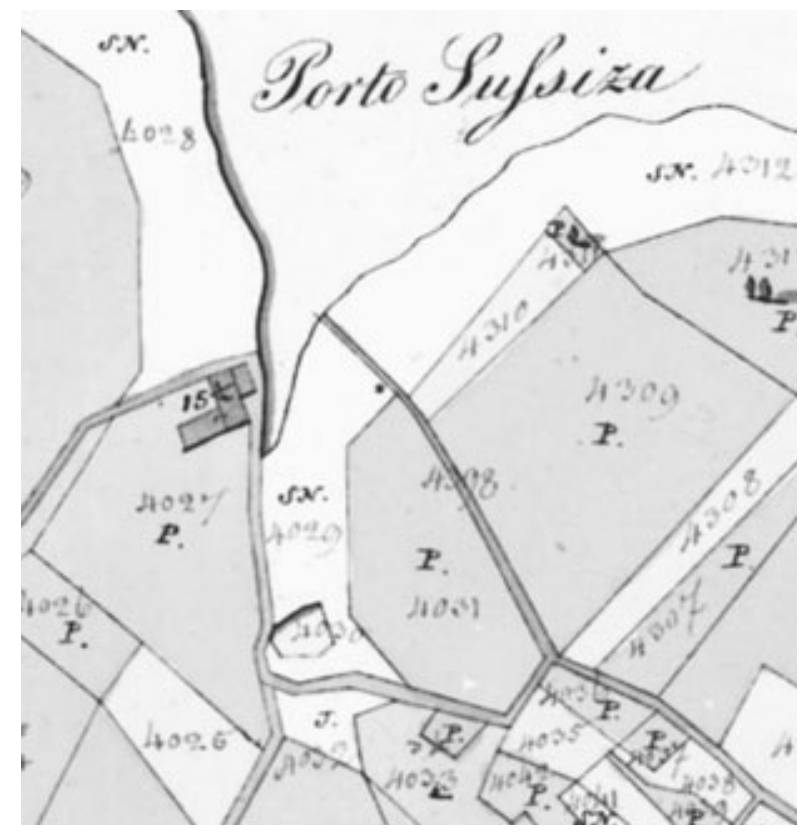

Slika 10. Detalj katastarske karte iz prve polovice 19. stoljeća s ucrtanim pištavcem u sredini uvale Sušica na otoku Ugljanu Izvor: www.mapire.eu

ograđivali. Vjerojatno je i ovdje riječ o istom fenomenu. Usp. Josip FARIČIĆ - Damir MAGAS̆, »Geografska obilježja i njihova funkcionalna povezanost s toponimima otoka Ugljana«, Toponimija otoka Ugljana, Vladimir SKRAČIĆ (ur.), Zadar, 2007., str. 20.

${ }^{218}$ I. ANZULOVIĆ, »Lučino selo«, str. 438, 444.

${ }^{219}$...iusto come sta la cantonada con il fosso della chaldrera del Rosa, et a dretta linea uerso prouvenza fin al confin de Didichi, e fino al mar et li horti del Rosa sia proindiuiso per causa della detta agua. HR-ASSMZD, Inventario, fol. $11 \mathrm{r}$. 
Četvrtina ostatka šume veličine sedam gonjaja i 50 pertika sa sljedećim granicama: s JI dijelom plemić Rosa, dijelom Bartolomej de Marchi, s JZ zemljište Šimuna de Marchi, sa SZ didići, sa SI nepodijeljeno zajedničko zemljište zbog pristupa vodi, pripala je plemiću Rosa. ${ }^{220}$

Osobita pozornost pri diobi posvetila se zemljištu na položaju Krševo (Cherseuo). Zemljište je bilo u jednom komadu, veličine 86 gonjaja, 1 kvarte i 72 pertike, a bila je riječ o oranicama, maslinicima, vinogradima, šumovitom tlu i izvorima vode. Pri diobi, koju je obavio plemić Juraj Kašić, samostanu sv. Katarine i braći De Marchi pripalo je 57 i 3/4 gonjaja i 60 pertika površine, dok je plemiću Francescu Rosi pripalo 28 i 2/4 i 42 pertike, koji su se protezali sa zapadne strane (dalla banda ponentale). S obzirom da se ta površina trebala podijeliti na četiri jednaka dijela, odnosno svakome od djeljenika trebalo je pripasti 21 i 2/4 gonjaja i 50 i 1/2 pertika, razvidno je da je plemiću Rosi dodijeljeno oko sedam gonjaja površine više. Sudac djelitelj Ventura pozvao se na staru diobu što su je izvršili kapetan Pelegrin De Marchi i Martin Meštrović. Zanimljiv je podatak da je plemić Rosa na položaju Krševo prionuo poboljšanju kvalitete nezakonito stečenih zemljišta, zbog čega je u novoj diobi naglašeno da bez obzira na to nema pravo potraživati novčanu odštetu za taj trošak, a konačno je površina njegovih posjeda svedena na četvrtinu, odnosno 21 i 2/4 gonjaja i $501 \frac{1}{2}$ pertika. ${ }^{221}$

\section{Zaključak}

Uvidom u inventar posjeda samostana sv. Katarine te komparacijom dostupnih izvornih podataka s dosad objavljenim rezultatima istraživanja u literaturi u radu se pokazalo da su mletačko-osmanski sukobi u 16. stoljeću imali znatan utjecaj na agrarno poslovanje u zadarskom okruženju u razmatranom razdoblju. Najplodnije zemljišne čestice prostirale su se u dubini zadarskoga okruženja, a nakon mletačko-osmanskoga razgraničenja u drugoj polovici 16. stoljeća one su bile nepovratno izgubljene ili nekultivirane te zemljoposjednicima nisu donosile nikakva prihoda. Zbog stalne opasnosti od osmanskih upada razvidno je da su crkveni i svjetovni posjednici nastojali širiti svoj zemljoposjed na zadarskim otocima, a na mletačkom dijelu kopnenoga okružja nastoji se zaštiti kolone i posjed izgradnjom kula i utvrda, odnosno stvaranjem obrambenoga sustava oko zemljoposjednikova selišta (villa). Na taj način zemljoposjednikovo selište nerijetko postaje temelj razvitka novoga naselja. Primjer posjeda u Glupavcima (Gornje Petrčane) u vlasništvu ženskoga benediktinskog samostana sv. Katarine u Zadru zorno potkrepljuje tu tezu. Analiza i sinteza prikupljenih podataka o samostanskom posjedu u Gornjim Petrčanima pokazuju vrijednost istraživanja dostupnih izvornika o posjedima crkvenih institucija za promatranje onomastike i toponimije pojedinih područja u 16. stoljeću. Pritom se otvara prostor za nova promišljanja o lokalnim migracijama stanovništva na zadarskome području upravo kroz prizmu brojnih kolonatskih ugovora koji su zabilježeni u samim inventarima i spisima javnih bilježnika, a nisu u tom smislu dovoljno valorizirani. Nadalje, sačuvani

\footnotetext{
${ }^{220} \mathrm{HR}-\mathrm{ASSMZD}$, Inventario, fol. $11 \mathrm{v}-12 \mathrm{r}$.

${ }^{221}$ Isto, fol. $11 \mathrm{r}-\mathrm{v}$.
} 
arhitektonski sklopovi nekadašnjih selišta (villa), odnosno nastambi kolona, kula i utvrda, kao što je očito na primjeru Gornjih Petrčana, pružaju priliku za istraživanje stambene kulture u selima zadarskoga zaleđa u 16. stoljeću, tim više što je u historiografiji zapažen manjak istraživanja te vrste. Uz to, naznake granica posjeda u inventarima, njihovih vlasnika i kolona koji su ih obrađivali, kao i zapisi o diobama zemljišta, izvrsno su vrelo za promatranje vertikalne društvene diferencijacije u 16. stoljeću. Sve navedeno, mišljenja smo, opravdava buduće istraživačke napore u tom smjeru, što je svrha i ovoga skromnoga priloga o posjedima samostana sv. Katarine u Zadru u 16. stoljeću.

\section{SUMMARY}

POSSESSIONS OF THE BENEDICTINE MONASTERY OF ST CATHARINE IN ZADAR $\left(16^{\text {th }}\right.$ CENTURY)

Author analyzes unpublished inventory of the Benedictine monastery of St Catharine in Zadar that dates back to 1599. The inventory is kept in the Archives of Benedictine monastery of St Mary in Zadar. Since this inventory precisely registers geographical location, size, incomes and workers (serfs) on the possessions of the female Benedictine monastery of St Catharine in the sixteenth century, author analyzes economic aspects of monastery community that accepted only women Zadar bourgeoisie social stratum. Moreover, inventory data from the late sixteenth century is compared with the report of monastery's procurators from the period between 1562 and 1564, which is presently kept in the State Archives in Venice.

KEY WORDS: Monastery of St Catharine, Zadar, Benedictine sisters, possessions, $16^{\text {th }}$ century. 